\title{
NORTHWEST MONTANA WILDLIFE MITIGATION HABITAT PROTECTION ADVANCE DESIGN
}

\author{
FINAL REPORT
}

\author{
Prepared by: \\ Marilyn A. Wood, Project Biologist \\ Montana Department of Fish, Wildlife and Parks
}

Prepared for:

Robert Walker, Project Manager

U.S. Department of Energy

Bonneville Power Adminstration

Division of Fish and Wildlife

P.O. Box 3621

Portland, OR 97283-3621

Project Number 87-60

Contract Number DE-A17947BP36137

FEBRUARY 1993 
TABLE OF CONTENTS

LIST OF TABlES . . . . . . . . . . . . . . . . . . . . . . . . . . . . iv

LIST OF FIGURES . . . . . . . . . . . . . . . . . . . . . . . . . . . . . . v

LIST OF APPENDICES . . . . . . . . . . . . . . . . . . . . . . . . . . . . vi

ABSTRACT . . . . . . . . . . . . . . . . . . . . . . . . . . . . . vii

INTRODUCTION . . . . . . . . . . . . . . . . . . . . . . . . . . . . . . I

Project Scope .. . . . . . . . . . . . . . . . . . . . 1

Project Objectives . . . . . . . . . . . . . . . . . . . . . . . . . .

HABITAT PROTECTION IMPLEMENTATION PROCESS . . . . . . . . . . . . . . . . . 3

Introduction . . . . . . . . . . . . . . . . . . . . . . . . . . 3

The Technical Committees . . . . . . . . . . . . . . . . . . . . . 3

The Advisory Committee . . : . : . : . : . : . . . : . : : : . 3

Summary of Implementation Process . . . . . . . . . . . . . . . . . . 4

WATERFOWL/WETLANDS PROGRAM . . . . . . . . . . . . . . . . . . . . . . . 7

Introduction . . . . . . . . . . . . . . . . . . . . 7

Technical Committee . . . . . . . . . . . . . . . . . . 7

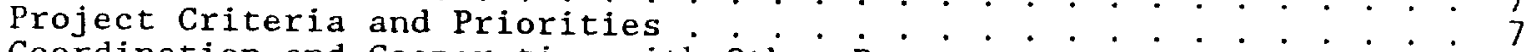

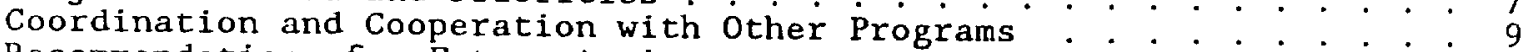

Recommendations for Future Actions . . . . . . . . . . . . . . . . 10

GRIZZLY BEAR/BLACK BEAR PROGRAM . . . . . . . . . . . . . . . . . 11

Introduction . . . . . . . . . . . . . . . . . . . . . . . 11

Technical Committee . . . . . . . . . . . . . . . . . . 12

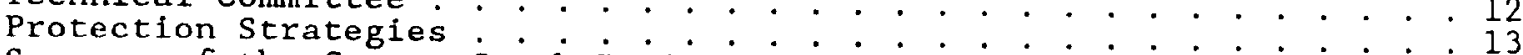

Summary of the Copper Creek Project. . . . . . . . . . . . . . 14

Recomnendations for Future Actions . . . . . . . . . . . . . . . . . . 14

COLUMBIAN SHARP-TAILED GROUSE PROGRAM . . . . . . . . . . . . . . . . . . . 18

Introduction . . . . . . . .... . . . . . . . . . . . . . . . 18

Technical Committee . . . . . . . . . . . . . . . . . 18

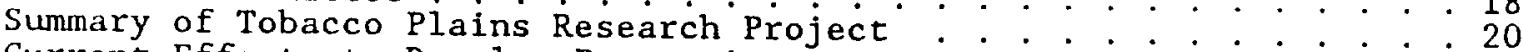

Current Efforts to Develop Protection Strategies

on the Tobacco Plains... . . . . . . . . . . . . . . . . . 21

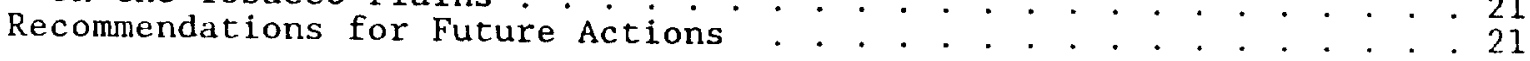

TERRESTRIAL FURBEARER PROGRAM . . . . . . . . . . . . . . . . . . . . . 22

Introduction . . . . . . . . . . . . . . . . . . . 22

Sumnary and Opportunities with Dept. of state Lands : : : : : : : : : 22

Recommendations for Future Actions . . . . . . . : : : : : : : 24

PILOT PROJECT - THE ROCKY BAR O RANCH . . . . . . . . . . . . . . . . . . 25

Introduction . . . . . . . . . . . . . . . . . 25

Previous Protection Efforts .

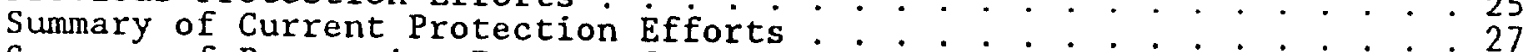

Sumnary of Protection Process for the Rocky Bar o Ranch : . . . : . : 29

Summary of Habitat Protected . . . . . . . . . . . . . . . . . . . 30 


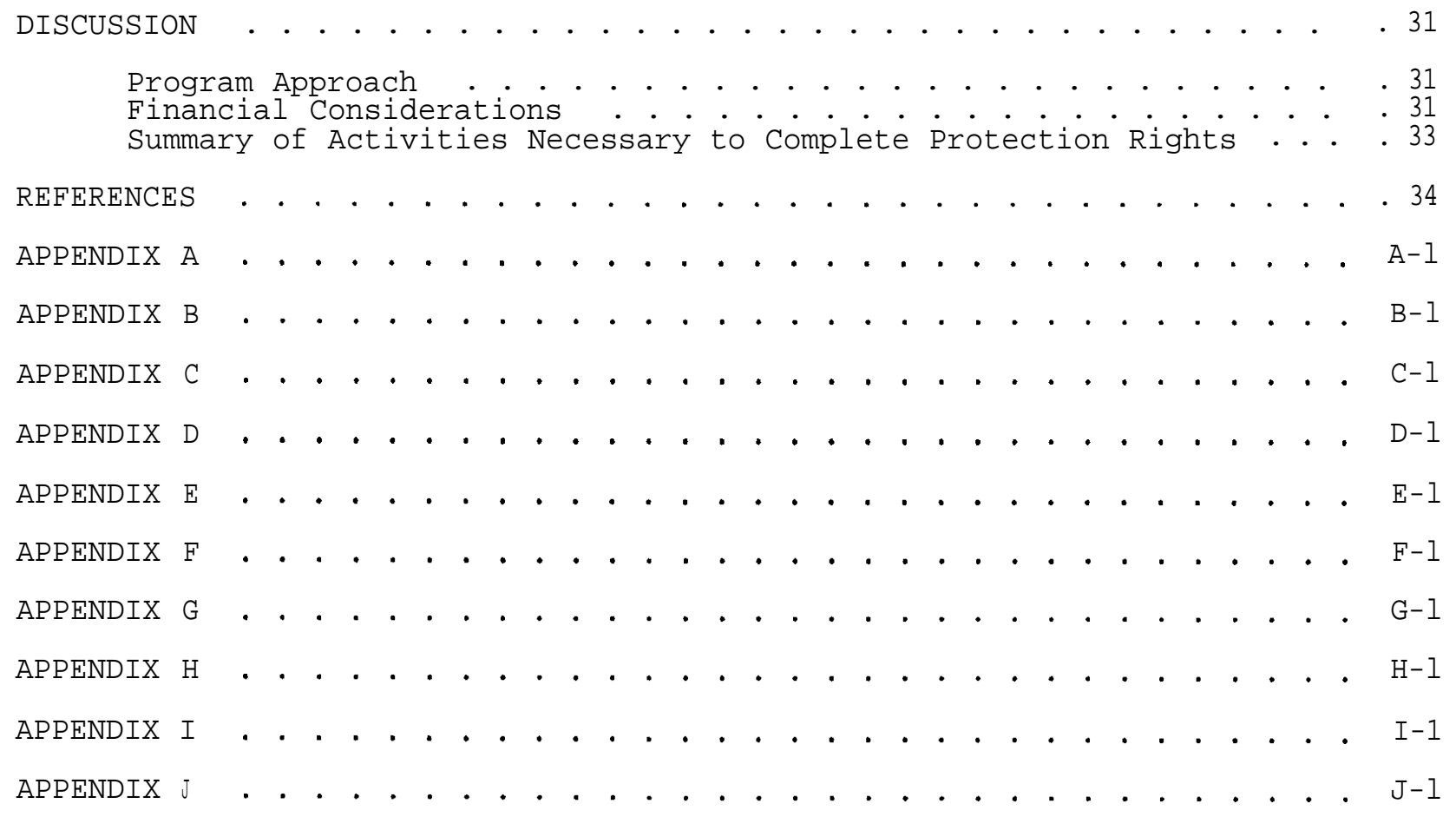

\section{i i i}


$\underline{\text { Table }}$

1 Wildlife mitigation goals adapted from Measure 1003 (b) (4) Table 4 of the Columbia River Basin Fish and Wildlife Program).

2 Summary of cooperative efforts to protect bear habitat with the Copper Creek project.

3 Summary of wildlife habitat protected on the Rocky Bar 0 Ranch. 


\section{LIST OF FIGURES}

Eigure

1 Administrative pathways for implementing wildlife mitigation habitat protection projects.

2 General location of the Copper Creek conservation easement project.

3 General location of the Rocky Bar 0 Ranch, North Fork of the Flathead River, Montana. 
A. General proposal format for habitat protection projects . . . . . A-1

B. Waterfowl/Wetland project evaluation form to review potential waterfowl projects . . . . . . . . . . . . . . . . . . B-1

C. Current format for management plans on MDFWP Wildlife Management $\mathrm{A} r$ e a s.......................... . C C-1

D. Bear habitat protection site evaluation form to rank potential projects . . . . . . . . . . . . . . . . . . . . . D-1

E. The Copper Creek conservation easement . . . . . . . . . . . . E-1

F. The Potentially Affected Interests (PAI's) identified on the Columbian sharp-tailed group program. . . . . . . . . . . . . F-1

G. The report on the Columbian sharp-tailed grouse population on the Tobacco Plains, Eureka, Montana. . . . . . . . . . . . . G-1

H. The financial analysis of the Bear Creek canyon proposed scenic easement by the Department of State Lands. . . . . . . . . . . . . H-l

I. The Department of State Lands scenic easement on the Soup Creek

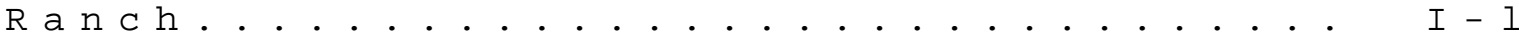

J. The Rocky Bar 0 Ranch conservation easement . . . . . . . . . . . . J-1 
ABSTRACT

This report summarizes the habitat protection process developed to mitigate for certain wildlife and wildlife habitat losses due to construction of Hungry Horse and Libby dams in northwestern Montana. The project, funded by Bonneville Power Administration, was initiated in 1987. Project objectives were to: (1) develop an implementation process for habitat protection using conservation easements, fee acquisition, or lease agreements; (2) identify program objectives and critical sites for grizzly and black bears, waterfowl, and Columbian sharp-tailed grouse; (3) initiate a pilot project, and; (4) determine the feasibility of obtaining cooperative agreement with Department of state Lands and other landowners to protect terrestrial furbearer habitat.

An implementation process was developed to identify cost-effective mitigation projects that achieve biological objectives and promote cooperation and coordination with other agencies and private organizations. Three technical committees were established to identify goals and objectives for each program and develop criteria for projects. A broad-based advisory committee was established to provide MDFWP with diverse perspectives on program direction and review merits of individual projects. A process for implementing projects was described.

Program objectives and priority projects for each species or species group were identified. Objectives for the waterfowl/wetland program include protecting existing productive areas that are threatenedwit loss or destruction and threats is a low priority. The grizzly bear/black bear habitat protection efforts will focus on low elevation riparian areas and adjacent uplands. Conservation easements or fee acquisitions will provide open space (secure habitat) and minimize potential for human/bear conflicts. Easements condition guidelines were identified. A six-month research project was completed to determine the feasibility of maintaining a sharp-tailled grouse population on the Tobacco Plains. Recommendations included protecting the known occupied habitat and the need to identify other critical habitat requirements. A two-year graduate student project was initiated to identify critical nesting and brood rearing habitat for Columbian sharp-tailed grouse.

The feasibility of developing a protection plan for terrestrial furbearers was determined. Department of state Lands is interested in discussion compensation of school trust funds for timber harvest management. Example agreements are presented and steps necessary to pursue agreements are identified.

Two pilot projects are described. A conservation easement to protect 107 acres of bear habitat on Copper Creek was established. The protection efforts on the Rocky Bar 0 Ranch were described and resulted in protection of approximately 1,094 acres of critical bear habitat. 
INTRODUCTION

Mitigation plans for Libby and Hungry Horse dams were developed by the Montana Department of Fish, Wildlife and Parks (MDFWP) in 1984 and 1985, respectively. The Libby Dam mitigation plan (Mundinger and Yde 1984) identified eight mitigation projects that addressed priority species and offered the opportunity to accomplish mitigation for other species as secondary benefits. The Hungry Horse mitigation plan (Bissell and Yde 1985) proposed seven wildlife mitigation measures. Both plans recommended mitigation alternatives that included enhancement of existing habitats to increase population numbers, development of management or protection strategies for species where inadequate information exists, and habitat protection through conservation easement or fee-title acquisitions for certain species where enhancement of existing habitat was not appropriate or feasible.

After public review and comments on these plans, the Northwest Power Planning Council (Council) in 1987 adopted modified mitigation alternatives for both Libby and Hungry Horse dams. For grizzlybears, black bears, Columbian sharp-tailed grouse, waterfowl, and terrestrialfurbearers the Council's Columbia River Basin Fish and Wildlife Program included the protection of important habitat as the most effective mitigation strategy. Habitat protection could be accomplished through the use of conservation easements, fee-title purchases and/or cooperative agreements with landowners. The program also recognized the value of an advanced design phase requiring 1-2 years to identify potential sites, develop interagency coordination, and define the protection process.

\section{Project Scope}

Because the mitigation plans for both Hungry Horse and Libby dams identified habitat protection as the preferred alternative for certain wildlife species, a single project was initiated to develop protection strategies for both hydroelectric facilities. In September 1987, Montana Department of Fish, Wildlife and Parks, under contract with Bonneville Power Administration (BPA), initiated the Northwest Montana Habitat Protection Project. The combined mitigation goals became the objectives for this project (Table 1).

The purpose of this project was to develop the process for implementing habitat protection plans for the target species. This process would provide the frame work for a cost-effective program that adequately mitigates the wildlife losses and complements on-going management programs.

Project Objectives

Specific project objectives include:

1. Develop a process for implementing a habitat protection program that integrates various agencies and private organizations and complements on-going programs.

2. Develop protection plans for grizzly and black bears, waterfowl, and Columbian sharp-tailed grouse that include mitigation objectives, criteria, and identify potential projects.

3. Initiate a pilot project that outlines the procedure necessary to complete either a fee-title acquisition or a conservation easement.

4. Determine the feasibility of developing cooperative agreements with Montana Department of State Lands and others to protect habitat for terrestrial furbearer habitat. 
Table 1. Wildife mitigation goals (adapted from Measure 1003 (b) (4)---Table 4 of the Columbia River Basin Fish and Wildlife Program).

\begin{tabular}{|c|c|c|c|}
\hline Project Area & Target Species & $\begin{array}{l}\text { Wildlife or } \\
\text { Habitat Losses }\end{array}$ & Mitigation goal \\
\hline \multirow[t]{3}{*}{$\begin{array}{l}\text { Hungry Horse } \\
\text { Dam }\end{array}$} & $\begin{array}{l}\text { Grizzly Bear/ } \\
\text { Black Bear }\end{array}$ & $\begin{array}{l}8,590 \text { acres of } \\
\text { critical habitat }\end{array}$ & $\begin{array}{l}\text { Protect riparian } \\
\text { habitat and travel } \\
\text { cooridors. }\end{array}$ \\
\hline & Waterfowl & $\begin{array}{l}1,146 \text { acres of } \\
\text { prime habitat }\end{array}$ & $\begin{array}{l}\text { Protect and/or } \\
\text { enhance wetland } \\
\text { habitat }\end{array}$ \\
\hline & $\begin{array}{l}\text { Terrestrial } \\
\text { Furbearers }\end{array}$ & 11,050 acres & $\begin{array}{l}\text { Protect selected old } \\
\text { growth forest using } \\
\text { cooperative agree- } \\
\text { ments on state! } \\
\text { federal, or private } \\
\text { lands }\end{array}$ \\
\hline \multirow[t]{2}{*}{ Libby Dam } & $\begin{array}{l}\text { Columbia Sharp- } \\
\text { tailed grouse }\end{array}$ & 2,462 acres & $\begin{array}{l}\text { Protect prairie } \\
\text { habitat within the } \\
\text { vicinity of the } \\
\text { Tobacco Plains }\end{array}$ \\
\hline & Waterfowl & $\begin{array}{l}3,418 \text { acres of } \\
\text { prime habitat }\end{array}$ & $\begin{array}{l}\text { Protect and/or } \\
\text { enhance } 3,418 \text { acres } \\
\text { of wetland habitat }\end{array}$ \\
\hline
\end{tabular}


HABITAT PROTECTION IMPLEMENTATION PROCESS

\section{Introduction}

A primary objective of this project during the advanced design phase was to provide a framework for implementinghabitatprotection strategies for the target wildlife species. The framework identifies an objective process that promotes development of a cost-effective mitigation program that includes cooperation and coordinationwith agencies and private organizations. This implementationprocess will:

1. Avoid duplication of efforts or overlap of existing habitat protection programs;

2. Develop a cost-effective program that identifies the critical habitat protection needs;

3. Identify the steps for developing and implementing individual projects, and;

4. Provide consultation with interested parties in addition to wildlife agencies normally responsible for management.

The implementation process involved a two-tiered approach. The first level involves biological input from technical committees. The second level involves project review by the Advisory Committee,

The Technical Committees

The technical committee's function as an advisory group that provides biological expertise on the individual species programs. Advice and recommendations developed by the technical committees are used to ensure biologically sound mitigation projects, Specific functions of the technical committees are:

1. To develop specific program objectives, suitable mitigation projects, and the criteria used to recommend potential projects;

2. To identify opportunities for cooperation in order to maximize habitat protection and/or reduce costs;

3. To identify specific management issues that need to be addressed, and;

4. To recommend appropriate strategies (easement, acquisition, management agreements) that adequately provide the necessary level of habitat protection.

Three committees were established: (1) the Waterfowl/Wetland Technical Committee; (2) the Grizzly Bear/Black Bear Technical Committee, and; (3) The Columbian Sharp-tailed Grouse Technical Committee.

The Advisory Committee

The role of the Advisory Committee is to provide public input, review and recommendations throughout the Habitat Protection Project. The intent of this second level of process is to have a broad based group that provides critical review of the entire project. 
Committee members were selected to represent various agencies and organizations that would provide MDFWP with diverse perspectives. During 1988 to 1990 , the following were represented on the Advisory Committee:

U.S. Fish and Wildlife Service

Flathead Land Trust

Flathead National Forest

Confederated Salish and Kootenai Tribes

Flathead Electric Cooperative

Department of State Lands

Flathead Conservation District

MDFWP/Flathead National Forest Mitigation Coordinator

Flathead Audubon Chapter

Flathead Wildlife, Inc.

Plum Creek Timber Company, Inc.

The functions of the committee are two-fold. First, the Advisory Committee reviews project proposals as recommended by the Technical Committees, Secondly, the committee serves a major role in public involvement.

Project proposals that are initiated by the Technical Committee are reviewed by the Advisory Committee. In cases where projects are proposed from more than one technical committee and funding is limited, the Advisory Committee makes recommendation using the following criteria:

1. Degree of need or immediacy of action required;

2. Cost Effectiveness and level of cooperation;

3. Other project benefits (multi-species), and;

4. Feasibility.

The Advisory Committee also serves an information exchange function. The committee provides an important communications link between MDFWP and other interested parties. This public involvement role is achieved by: (1) knowledge of the program direction and proposed activities; (2) identifying other Potentially Affected Interests (Bleiker and Bleiker 1986), and; (3) identifying issues not previously considered that may affect project implementation.

The specific role of the Advisory Committee has evolved during the advanced design phase of this project. The following recommendations will be incorporated in future committee meetings:

1. Meetings will be held quarterly in March, June, September, and December.

2. Newsletters will be issued between meeting to provide project updates.

3. Members will have a more active role by being responsible for providing information to the group.

4. Ongoing or proposed projects will be reviewed in the field by committee members.

Summary of Implementation Process

The administrative pathways for implementing habitat protection projects are outlined in Figure 1. The Council's Fish and Wildlife Program determines the overall mitigation objectives for the target species. The multi-agency technical 


\section{HABITAT PROTECTION PROJECT IMPLEMENTATION}

Identification and Feasibility

NWPPC's Fish and Wildlife Program

Technical Committees

1

Habitat Protection Advisory Committee

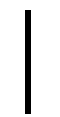

MDFWP Review and Recommendations

'”

Trust Advisory Committee Review and Recommendations

Implementation

County Commissioners, local legislators, and

County Planning Boards<smiles>C1CCCCC1</smiles>

Public Involvement

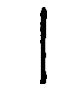

Fish and Game Commission

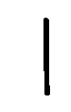

State Land Board

Figure 1. Administrative pathways for implementing wildlife mitigation habitat protection projects. 
committees provide advice on specific program objectives and criteria that assist MDFWP in developing biologically valid projects. Project proposals can be developed in two ways. Specific projects can be identified by the technical committee members and the proposal developed by MDFWP. Other interest or agencies outside the technical committee can develop project proposals. These proposals will be reviewed by the technical committees for biological merits and to determine whether the proposal meets the criteria for the specific mitigation program. A general proposal format is attached as Appendix A.

Proposed projects are next reviewedby the Habitat Protection Advisory Committee. Advisory committee members provide MDFWP with recommendations on individual projects and overall program objectives. These recommendations are reviewed by MDFWP staff and priority proposals are submitted to the Trust Advisory Committee for consideration.

As proposed projects are being considered, steps are being taken to determine the feasibility of project completion and to coordinate proposed activities with local governments. Any proposed action involving land ownership or land use changes will be coordinated through the county commissioners, the local legislators, and local planning boards.--Additional public involvement needs will be addressed specific to each proposed project.

Any fee-title acquisition or conservation easement activities that will be required to adhere to current habitat acquisition policies of the state. In general, this includes formal review by the state Fish and Game Commission and the State Land Board (MDFWP 1984). 
Introduction

The Council's Fish and Wildlife Program authorized BPA to fund projects to protect and/or enhance of 4,564 acres of prime wetland habitat as mitigation for waterfowl losses. In order to be consistent with current objectives of agencies responsible for waterfowl management, the primary mitigation objective should be directed toward increasingwaterfowl production. The North American Waterfowl Management Plan (1986) adopted by the USFWS and Canadian Wildlife Service identified the need for immediate actions to offset the substantial decline in waterfowl numbers throughout Canada and the United States. Loss of habitat was identified as the number one reason for the observed reduction in waterfowl numbers. The Plan identified acquisition or protection of important nesting and brood-rearing habitat as the primary tool to increase waterfowl numbers.

Generally, the preferred approach for wetland mitigation involves the restoration or creation of wetlands in order to achieve a "no-net loss" of wetland habitat. This premise also implies that acquiring or protecting existing, productive wetlands does not directly reduce or compensate for losses. Protecting existing wetlands with limited upland nesting opportunities would be considered appropriate mitigation if the adjacent uplands could be enhanced to provide greater nesting success. Projects that involve fee-title acquisition or conservation easements must have a reasonable probability of providing increased duck production. Purchase of land and transfer of ownership alone does not always assure that mitigation objectives are met.

\section{Technical Committee}

The Waterfowl Technical Committee is composed of staff from agencies responsible for waterfowl management and the Confederated Salish and Kootenai Tribes. During 1988 to 1990 the following agencies were involved:

U.S. Fish and Wildlife Service

Confederated Salish and Kootenai Tribes

Montana Department Fish, Wildlife, and Parks

University of Montana/USFWS Wildlife Management Cooperative Unit

Four formal meetings were held during the planning phase of implementation. Numerous informal contacts were made throughout the period. Meetings were held to develop program goals, identify potential projects, discuss management concerns, and select a pilot project.

\section{Project Criteria and Priorities}

The following priority categories were developed to provide program direction and identify where implementation efforts should be focused:

High Prioritv: Existing important waterfowl habitat that currently provides nesting and brood-rearing habitat and is seriously threatened with loss or degradation. Not protecting these sites would result in an overall loss to the local waterfowl population. Threats to the sites may be related to increased human development, loss of available water, or other factors that diminish the wetland or upland nesting values. In general, these sites are found on privately owned lands. 
Medium Priority: Enhancing marginally productive areas to increase waterfowl production. These sites may include areas that currently support limited duck nesting but with enhancement measures would provide additional successful nesting opportunities. These sites may occur on publicly or privately owned land.

Low Prioritv: Protecting existing quality wetlands or riparian areas with limited enhancement potential and a low risk of habitat loss. In some cases it may be appropriate to secure privately owned wetland complexes with long term management plans or conservation easements or in conjunction with other conservation programs.

An evaluation form was developed to provide an objective process for identifying high priority projects to consider (Appendix B). This form is simply a tool to provide consistent review of proposed projects. Determiningwhether a particular project fits the mitigation program should have an objective component, but ultimate decision making should be site specific. Some flexibility should also be allowed for case-by-case review of opportunities that become available and have not been previously considered.

The form attempts to place proposed projects in the appropriate priority category. The objective is not to label a particular project as more worthwhile than another, but to identify where initial efforts should be focused. In fact, all the projects undoubtedly have merit, but for this mitigation program certain projects may warrant more immediate attention.

The prioritization process was tested in November, 1988 when the Committee was asked to provide MDFWP with a recommendation on a pilot waterfowl project. Three waterfowl projects were reviewed and ranked based on a draft evaluation form. The projects reviewed included one project (Ashley creek Development) already listed as a priority by the USFWS, and two other projects that became available for consideration due to landowner circumstances (Crow Creek Ranch and Weaver's Slough). All projects were visited by the Committee members and then ranked individually.

The draft ranking process provided a good opportunity to refine the system. Initial ranking criteria were based on biological factors, management considerations, and an assessment of threats or vulnerability. Numerical scores were identified for each factor or criteria. We attempted to choose the top priority project (of the three) by the highest score. After lengthy discussions, it was obvious that the current system needed modification. However, it was evident that two projects (Ashley Creek Development and the Crow Creek Ranch) ranked significantly higher than the other project and a recommendation was made to pursue the Crow Creek Ranch project (Wood 1990). Based on this test several recommendations were developed to improve the prioritization process. These include:

a Process should rank both the existing conditions of the site and the potential conditions based on wetland development or enhancement.

- Numerical rankings for individual projects were inconsistent. A better method would provide a range of figures that would group projects into high, medium, and low priorities.

- Ranking factors or criteria should be discrete enough to allow distinction between sites.

The current evaluation form (Appendix B) identifies the biological merits of a project or a site. The intent is to categorize any known existing wetland sites and focus the protection strategies toward the most critical sites. Additional criteria are considered before a project is recommended for implementation. These include: 
Availability: The status of the land is determined.

Feasibility: Potential barriers to project completion are identified including water rights, hydrology, development needs.

Management: The appropriate agency or organization for long-term management is identified.

Type of Protection Needs: Protection tool is identified (fee title acquisition, easement, or long-term management agreement).

Coordination and Cooperation with Other Programs

In order to maximize effectiveness and avoid duplication of efforts other waterfowl/wetland programs were identified. In many cases, these programs can be used to complement this program.

U. S. Fish and Wildlife Service: The Fish and Wildlife service has agreed to accept management responsibilities, including all operations and maintenance costs for any properties acquired in fee that are on their list of potential sites. The Fish and Wildlife Service has identified approximately 4,800 acres for acquisition in Lake county. In Flathead County, they have identified approximately 11,500 acres of waterfowl habitat for protection. Limited federal acquisition funds are available for prairie pothole habitat acquisitions; however, there is potential for joint projects when proposed sites meet both the USFWS standards and the mitigat ion needs.

Ducks Unlimited: Project design and development are areas of Ducks Unlimited expertise. As potential projects are identified, Ducks Unlimited is willing to consider joint participation on approved projects. There is potential for numerous cooperative projects with Ducks Unlimited. In many cases it may be possible to acquire habitat with mitigation funds and have the development completed by Ducks Unlimited.

Montana Department of Fish. Wildlife and Parks: There are two programs within the state agency that complement the mitigation program. The state Duck stamp program offers the opportunit:y to fund enhancement projects on private or public lands. The upland bird habltat enhancement program provides some additional funding for projects that include wetland restoration, range management, and development of nesting cover.

The U.S. Forest Service: The Forest Service has a wildlife and fisheries Challenge Grant program that was initiated in 1986 to fund habitat improvements. Specifically for waterfowl, the "Taking Wing' program seeks to strengthen partnerships with other federal and state agencies and conservation groups to enhance waterfowl habitat management.

Kerr Mtigation: Montana Power Company recently submitted a mitigation plan for relicensin Kerr Dam to the Federal Energy Regulatory Commission (Montana Power Company, 1890). Wildlife habitat acquisition was identified as a maj part of the overall mitigation plan. Approximately 3,424 acres of wetland habitat will be acquired in the north half of Flathead Valley. Another 2,800 acres of wildlife habitat will be acquired in the south half of Flathead Valley.

State Highways Wetland Mitigation: The Montana Department of State Highways is identifying wetland impacted by highway improvements in northwestern Montana. In many cases, off-site mitigation will be required to compensate for wetland losses. State Highways has indicated an interest in cooperating on wetland projects that meet both our mitigation needs. 

follows:

1. A master list of all known potential waterfowl projects should be developed which incorporates the U.S. Fish and Wildlife Service acquisition list, and those of MDFWP. In many cases, these lists reflect properties that are available and not necessarily high priority projects. These projects should be prioritized according to the Committee recommendations and high priority, available sites should be pursued.

2. It is important to coordinate this mitigation program with the other waterfowl habitat acquisition plan of other agencies. Mitigation of wetland losses has become a focus recently in the Flathead Valley with the adoption of the Kerr Dam mitigation plan (Montana Power Co., 1990) and the need by the Department of State Highway's to mitigate the impacts of highway construction. The actual potential for good waterfowl projects that are available and feasible in the Flathead Valley may be less than the combined projected mitigation goals. It is readily apparent that there needs to be review of all wetland projects by cooperating agencies. It has been suggested that an Intermountain Waterfowl Committee be established to oversee waterfowl and wetland issues in northwestern Montana (J. Cross, personal communication).

3. Other opportunities to provide positive benefits to wetlands and waterfowl, besides outright acquisitions, should be explored. Efforts should focus on contacting willing landowners desiring assistance to provide better waterfowl habitat. Wetland developments and providing secure nesting habitat could be maintained through long-term agreements. Enhancement of existing publicly owned lands that currently provide marginal waterfowl habitat should be considered.

4. Management plans which outline project objectives, specific management concerns, and agency responsibilities need to be drafted for each project. These management plans could be adapted from the current format used for MDFWP Wildlife Management Areas (Appendix C). 
GRIZZLY BEAR/BLACK BEAR PROGRAM

Introduction

The Fish and Wildlife Program authorized BPA to fund projects to protect 8,950 acres of riparian habitat and travel corridors for grizzly and black bears in northwestern Montana. Habitat protection was identified as the preferred alternative because enhancement techniques for enhancing bear habitat on public lands (USFS) is of limited success or value. The mitigation plans specified that mitigation should occur on lands where secure habitat is at risk.

The Environmental Impact Statement on grizzly bear management (Dood et al. 1985) recommended habitat preservation as the key to the survival of the grizzlies. Human encroachment increases vulnerability and the probability of conflict. Improved access and development reduce the acreage of secure habitat for both grizzly and black bears.

The intent of this mitigation program will be to protect important bear habitat within the defined areas specified in the Grizzly Bear Recovery Plan (USDI 1982). This core habitat includes both the Northern Continental Divide Ecosystem and the Cabinet-Yaak Ecosystem where occupied habitat includes federal, state, and private ownership. The focus of the mitigation activities will be on areas where the current ownership or existing management provides less that 100 percent habitat effectiveness. Habitat effectiveness refers to the ability of the site to provide secure habitat for grizuly bear use. Habitat effectiveness of less that 100 percent indicates that some human-related aspect of the site reduces the quality of the area for grizzly bear use (e.g. low cover of preferred foods, limited hiding cover, presence of human development, etc.).

Specific objectives of the bear mitigation program are:

1. Provide open space or secure habitat for bear use and to minimize the potential for human-bear conflicts.

2. To protect low elevation riparian areas and associated uplands to provide important forage areas.

These objectives are consistent with --the Grizzly Bear Recovery Plan which identified strategies for maintaining a viable population of grizzlies. The mitigation objectives are compatible with the Grizzly Bear Management Plan which is currently being drafted for Region One of Montana Department of Fish, Wildlife and Parks.

Several areas within the Northern Continental Divide Ecosystem and The Cabinet Yaak Ecosystem contain private land where subdivision is presently occurring. Most of these private lands are located in low elevation riparian areas attractive to both bears and humans. The extent of land development in the NCDE was assessed by the Border Grizzly Project (Jonkel 1983). For instance, in the North Fork of the Flathead River, grizzly bears still have the opportunicy to use low elevation river bottom habitat with relatively low levels of human encroachment. However, this area also had the fastest growing development potential. Between 1950 to 1984, 584 parcels changedhands in the NCDE, of these 66 percent were located in the North Fork.

A similar situation is occurring in the Swan Valley. Between 1970 and 1980 , an 86 percent increase in housing units and a 78 percent increase in population had occurred. 


\section{Technical Committee}

The Grizzly Bear/Black bear Technical Committee is composed of agency personnel familiar with bear habitat requirements or with responsibilities for managing publicly owned lands within occupied habitat. During 1988 to 1990, the following agencies were involved:

U.S. Fish and Wildlife Service

U.S. Forest Service

Montana Department Fish, Wildlife and Parks

Glacier National Park

Meetings were held to develop overall objectives of the bear program, identify areas of focus, ranking process, and to develop easement restriction guidelines.

Based on discussions during the meetings, the following recommendations were made:

1. Mitigation projects must occur within the NCDE or the CYE.

2. Low elevation riparian areas or associated benchlands will be selected.

3. The sites must: (a) provide secure habitat through large acreages of undisturbed habitat; (b) minimize the potential for human-bear conflicts, and; (c) protect or enhance the forage quality.

4. Areas of focus will include: (a) the North Fork of the Flathead; (b) the Middle Fork of the Flathead; (c) the Swan Front; (d) the Swan Valley, and; (e) the Bull River.

In order to identify higher priority projects, several factors were considered. An evaluation form was developed which allowed several projects to be compared to help identify where efforts should be focused (Appendix D). This method is similar to a process developed by the Kootenai National Forest and MDFWP to identify mitigation priorities to address impacts of mining activities in the Cabinet Mountains (B. Summerfield, pers. comm.).

\section{Rating Criteria:}

1. Habitat Quality: Higher priority is given to sites which have the greater percentage coverage of quality bear habitat (including wet meadows, streams or river habitat, shrub or berry fields).

2. Bear Use: The known or estimated use of a site by bears is ranked.

3. Size of Tract: The site is rated by the acres available, with 1 point given for every 10 acres.

4. Existing Human Influence: Points are subtracted for the presence of any disturbances which may reduce the habitat effectiveness of the site.

5. Development Potential: This criteria measures the degree of threat to property and rates the type of threat or disturbance.

6. Adjacent Land Use: Sites are ranked according to adjacent land uses.

High priority sites should have rating scores which reflect areas that have high proportions of quality habitat, receive year-round use, are large in size, have limited or no human development but may be seriously threatened with changes, and are surrounded by areas with compatible grizzly bear management. 
Low priority sites will have scores which reflect areas that have little bear habitat, receive little or no use by bears, etc.

\section{Protection Strategi es}

Conservation easements on private lands will be the primary tool for protecting bear habitat. However, in some cases fee title acquisition will be pursued if the site is considered a high priority and/or the landowner is only interested in selling the property.

A list of potential easement restrictions was developed which addresses bear habitat concerns and provides a framework for easement negotiations.

Intent of the Easement:

1. To provide secure habitat;

2. To minimize existing and potential human/bear interactions;

3. To protect important habitat features such as forage areas, security cover, and travel corridors.

Examples of restrictions relevant to protection of open, secure habitat:

- No subdivision of the property

- Development is prohibited (homesites, cabins)

- Additional homesites or other structures can be limited in number, space, or location

- No commercial, professional, or industrial activities allowed.

Examples of restrictions relevant to minimizing human/bear conflicts:

- Bee keeping activities not allowed

- Orchards not allowed or limited to personal use only

- Keeping of pigs, sheep, or goats not allowed

- Garbage must be disposed regularly to avoid attracting bears

- Pet food, livestock food, and human food must be kept in a secure manner.

- Dead animals from livestock operations will not be placed in boneyard situations, nor placed near public access points

- Large calving operations or feedlot operations are not allowed

- Recreational developments that encourage long-term concentrated human use are not allowed

- Seasonal cabins must be bear-proof, including all food items (attractants) must be removed during vacancy

Examples of restrictions to protect habitat:

- Development of mineral and hydrocarbon rights may be prohibited

- Surface occupancy for mineral development is not allowed

- Specific restrictions on timing of activities, road placement, drill site placement, and on-site activities can be controlled

- Timber harvest practices must be compatible with currently recognized management guidelines for bear habitat

- Timber harvest plans must receive prior written approval by the appropriate management agency

- Livestock grazing practices which do not maintain bear habitat conditions are prohibited

- Wetland and riparian habitats are protected from draining, filling, or permanent flooding

- Additional roads which concentrate public access are not allowed 
Summary of the Copper Creek Project

In November, 1989, MDFWP was approached by Mr. Charles Evans of Libby regarding protection of wildlife values on his property near the Bull River valley. Mr. Evans wished to donate a conservation easement on 107 acres in the Copper Creek drainage. The property is completely surrounded by the Kootenai National Forest and is located approximately three-fourths of a mile from the Cabinet Wilderness boundary (Figure 2). The Cabinet Wilderness area is the site of extensive mineral development by the Asarco and Noranda corporations. Development associated with the mine is expected to impact several drainages. The landowner desired to protect his property from any future developments.

The property includes timbered slopes, open pastures, and riparian habitat along Copper Creek. A number of wildlife species occupy the property (J. Brown, pers. comm.). The timbered bottomlands provide white-tailed deer winter range and habitat for ruffed grouse and mink in the riparian areas. Elk occupy the grassy areas in spring and use the south-facing slopes during winter. The area is extensively used by black bears. It is assumed that grizzly bears will also occupy the property as their numbers increase with the U.S. Fish and Wildlife Service augmentation efforts (USDI 1987).

The Cooper Creek project was reviewed by both the Grizzly Bear/Black Bear Technical Committee and the Habitat Protection Advisory Committee. Both committees recommended pursuing the conservation easement.

The project involved cooperation of the landowners (The Copper Creek Conserve), MDFWP. and The Nature Conservancy (Table 2). In exchange for the donated conservation easement, MDFWP agreed to fund the easement appraisal and the documentation report. The independent appraisal was completed on June 30, 1990, and is on file in the Region One headquarters of the Montana Department of Fish, Wildlife and Parks. The appraisal was purchased with MDFWP general funds $(\$ 3,200)$. A contract to prepare the documentation report was awarded to an independent consultant familiar with this type of report and is expected to be completed by August 15, 1990. The documentation report provided baseline information on the existing conditions of the property, and identified easement conditions necessary to protect the wildlife values.

A conservation easement was jointly developedby MDFWP and The Nature Conservancy (Appendix E). The easement limits further development on the property and contains restrictions that reduce the potential for human/bear conflicts. The Nature Conservancy agreed to administer the conservation easement. Since the easement term is "perpetuity", this represents a significant contribution to the project. Generally, The Nature Conservancy requests one-time donations to establish a stewardship fund to monitor the easement. The Conservancy generally estimates stewardship costs at ten percent of the easement value (B. Hall, personal communication).

Recommendations for Future Actions

1. The mitigation project should continue to explore cooperative projects with the Flathead National Forest's Wild and Scenic River program on the north and middle fork of the Flathead River. Opportunities to protect important bear habitat, as determined by the ranking process, should be coordinated with ongoing efforts by the Forest Service. Priority sites should be identified for these areas.

2. Habitat protection strategies should be coordinated with the management plans currently being developed for other areas where human encroachment is occurring. These areas include the Mud Lake are of the Swan Front, Haskill Basin, and the Blakenship bridge area. Conservation easements to 


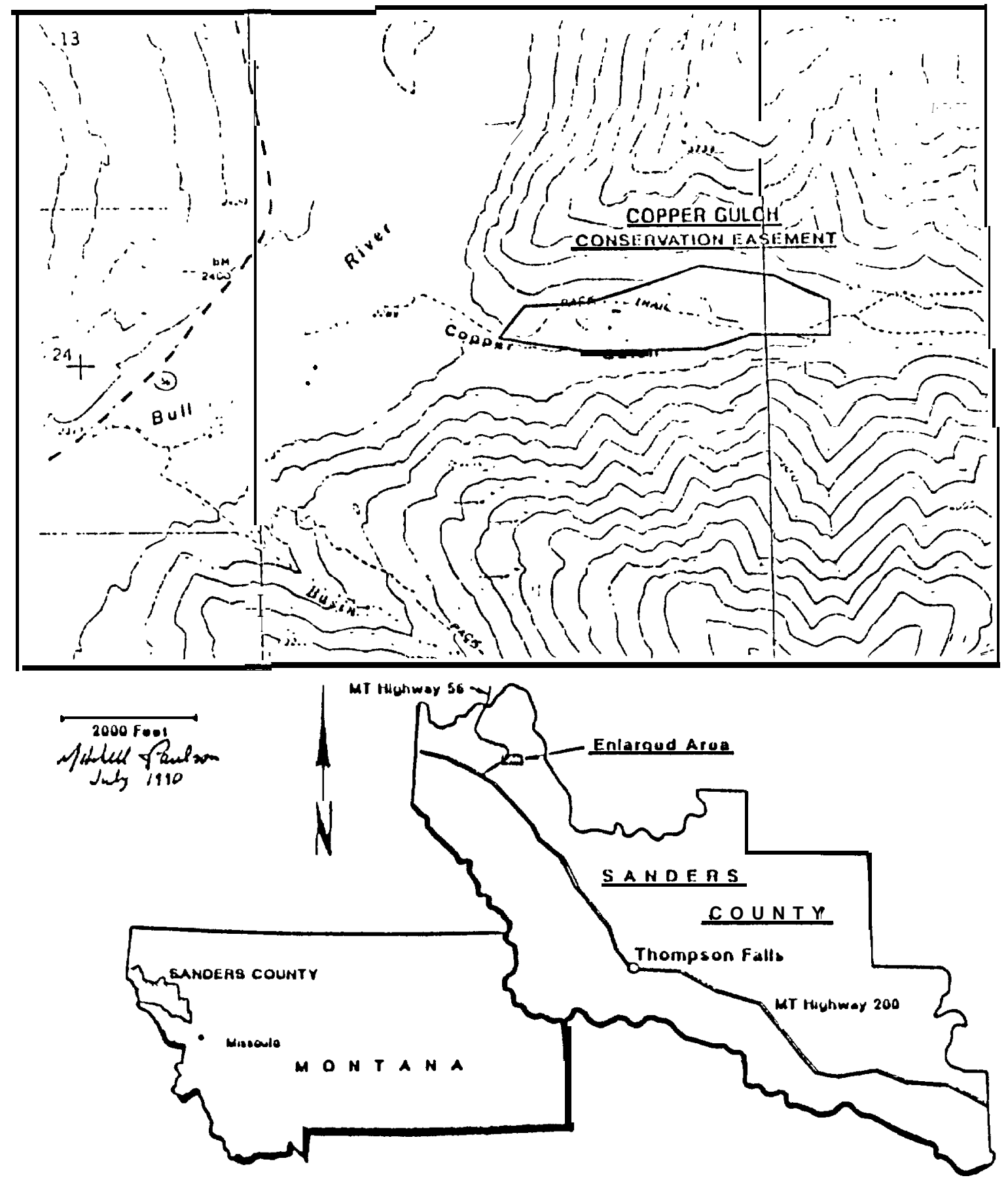

Figure 2. General I ocati on of the Copper Creek conservation easement project. 
Table 2. Summary of cooperative efforts to protect bear habitat with the Copper Creek project.

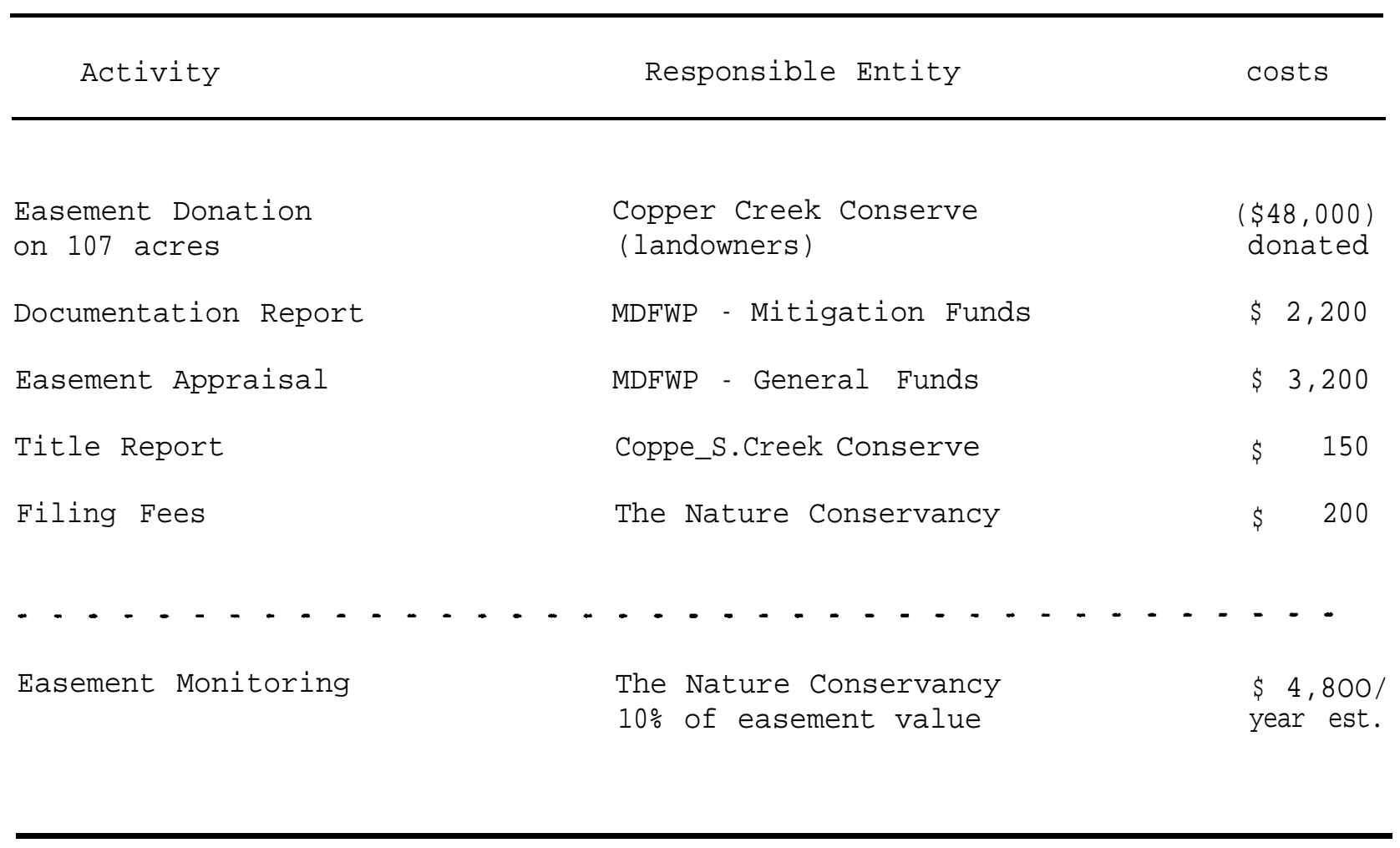


prohibit further development in additional to educational programs will be necessary to reduce the potential for human-bear conflicts.

3. The habitat protection program should also be coordinated with the mitigation plans currently being developed for the Noranda and Asarco mining activities in the Cabinet Wilderness area. Where mitigation objectives overlap, cooperative projects should be identified and pursued.

4. Opportunities to facilitate land trades advantages to protection of bear habitat should be pursued. Plum Creek, Inc. and the Department of State Lands are currently negotiating land swaps that would involve numerous sections of land in the Swan Valley. Parcels containing important bear habitat should be identified and, where possible, facilitating the trade from Plum Creek to State Lands ownership should be attempted. 


\section{Introduction}

The Council's Fish and Wildlife Prcgram authorized BPA to fund prejects to protect and/or enhance 2,462 acres of habitat for Columbian sharp-tailed grouse. Inundation of the Kootenai River Valley by construction of Libby Dam resulted in the loss of grassland and riparian habitat occupied by Columbian sharptails (Yde et al. 1984). The significanc of these habitat losses is magnified when considered with the overall decline of Columbian sharptails throughout northwestern Montana. At the time of Libby Dam construction, Columbian sharptails were confined to small areas in Lake, Powell, and Lincoln (the Tobacco Valley) counties where stands of native prairie remained (Hand 1969).

When the mitigation plans for Libby Dam were developed (1984), the only remaining active dancing ground (lek) in Montana was found on Tobacco Plains east of Lake Koocanusa. The population had declined steadily since 1976 (Manley, 1989). In 1987, biologists observed only three males on the dancing ground. With the eminent threat of losing the entire Tobacco Valley population, The Nature Conservancy and the Montana Natural Heritage Program initiated a conservation plan to augment the dancing ground with grouse transplanted from British Columbia. The intent of the Conservancy's plan was to maintain the active lek while attempting to secure important habitat.

In light of the declining Tobacco Plains grouse population and lack of documentation on the success of augmentation efforts, we decided to determine the feasibility of successfully maintaining a grouse population before proceeding with habitat protection. Specific goals of the Columbian Sharp-tailed Grouse Program are:

1. To determine the feasibility of maintaining a viable population of sharptailed grouse on the Tobacco Plains.

2. To identify critical habitat requirements necessary to maintain a population of sharptails.

3. Develop protection strategies to protect these critical habitats.

To address these goals, a short-term research project was conducted during 1989 on the Tobacco Plains. Objectives of this project were to document the success of augmentation efforts and to identify the reasons for the decline of the grouse population. In 1990, a two-year graduate student project was initiated to identify critical nesting and brood-rearing habitat occupied by grouse on the Tobacco Plains.

\section{Technical Committee}

The Columbian sharp-tailed grouse techhical committee is composed of several agencies and non-profit groups interested in maintaining sharp-tailed grouse in northwestern Montana. Committee members as of 1990 represented:

Kootenai National Forest

U.S. Fish and Wildlife Service

Confederated Salish and Kootenai Tribes

The Nature Conservancy

Montana Natural Heritage Program

Bureau of Indian Affairs

Montana Dept. Fish, Wildlife and Parks 
Five formal meetings of the sharptail grouse committee were held with numerous informal contacts made. The purpose of the meetings was to provide a common forum for those interested in Columbian sharptails to coordinate their actions and direction. Initial meetings focused on reviewing the status of known populations of sharptails and discussing current efforts to augment the declining population on the Tobacco Plains. The Technical Committee provided the opportunity for improved coordination of grouse recovery efforts. Transplant efforts in 1988 and 1989 were coordinated between The Nature Conservancy and MDFWP. The Nature Conservancy provided funds and equipment for trapping and transporting grouse release on the Tobacco Plains. MDFWP provided assistance during the grouse release and monitored the dancing ground to document transplant results.

The status of other remnant grouse populations in western Montana was discussed. According to field research conducted by Bureau of Indian Affair biologists, Columbian sharp-tailed grouse have not been observed on the Flathead Indian Reservation for the past ten years (D. Becker, pers. comm.). Tribal members recalled abundant grouse historically. Only limited suitable habitat remains within the reservation boundaries.

Most available habitat has been degraded by intensive livestock grazing. The Tribal Council has expressed an interest in establish a sharptails on the reservation. In 1980, Columbian sharptails were re-introduced on the National Bison Range in a cooperative effort between the U.S. Fish and Wildlife Service and the University of Idaho (H. Null, pers. comm.). Five hens and 32 chicks were release in early summer. In 1981, only one grouse remained. Grouse have not been observed on the Bison Range since that time. The National Bison Range has approximately 18,000 acres of native grasslands and coniferous forests in good condition. The Fish and Wildlife Service has expressed an interest in managing for sharptails on the Bison Range if re-introduction efforts can be developed with reasonable success.

Based on the available data, the Technical Committee recommended obtainimg additional information on the feasibility of maintaining a population of sharptails on the Tobacco Plains prior to acquiring easements or fee-title. Committee members developed the objectives for the short-term research project. In addition, the Technical Committee also identified the Potentially affected Interests (PAI's) as part of any public involvement process (Appendix F).

Based on the information obtained by Tim Manley and the recommendations of Dr. Eng, a Montana State University professor familiar with sharp-tailed grouse research, the Committee members developed a prioritized list of efforts for the Columbian Sharp-tailed Grouse Program:

1. Protect existing occupied habitat, including the active lek and known or potential wintering areas.

2. Identify important nesting and brood rearing habitat by radio tracking hens with broods and develop strategies to protect these sites.

3. Determine the feasibility of re-introductions on the National Bison Range and identify the potential for cooperative projects.

4. Continue to identify other possible grouse populations, particularly in the Helmville-Drummond area.

5. Develop cooperative agreements with the CSKT for sharptail reintroduction and habitat management on reservation lands.

6. Support USFWS efforts to conduct genetic testing to determine subspecies differences. 


\section{Summary of the Tobacco Plains Feasibility Report}

The complete reoort based on a 6 month research oroiect is attached as Appendix

G. The following summarizes some of the important-results of this project:

1. Evidence suggests that grouse occupied suitable habitat on the Tobacco Plains, including the areas inundated by Libby Dam.

2. Three confirmed dancing grounds were documented; however, only one ground is currently active. The highest observed total counts on dancing grounds occurred in April $197^{\prime} 1$ when 54 grouse were observed. A steady decline in grouse numbers occurred since 1976. By spring 1988 only 3 males were observed.

3. Lek observations revealed that transplanted birds from 1987, 1988, and 1989 had survived and returned to occupy the lek.

4. Winter habitat use occurred on deciduous shrub and trees on private lands.

5. Habitat changes between 1947 and 1987 were determined from aerial photos. Native grasslands decreased by 18 percent. Increases were documented for both residential development and agricultural uses. It was not possible to identify any qualitative changes in the grassland communities.

6. Habitat currently available for grouse use was ranked by habitat quality and existing and historic use by grouse. The highest priority for protection is section 23 which contains the only active lek. High priority winter habitat was located east of Highway 93 and included approximately 15.6 square $\mathrm{km}$.

7. Types and amounts of habitat were similar in the Tobacco Plains and the same size area in Kamloops, British Columbia. The major difference appeared to be the better quality of grasslands available in the Kamloops area.

8. Areas north of the Tobacco Plains (border to Cranbrook, B.C.) historically supported sharp-tailed grouse. However, forest encroachment on grasslands, heavy cattle grazing, and residential development are believed to be responsible for the decline of grouse in that area.

9. No information is available on nesting and brood rearing habitat in the Tobacco Plains. These sites need to be identified and protected.

10 Although the direct cause of the sharptail population decline is unknown, numerous factors were probably responsible, including: (a) habitat degradation -overgrazed grasslands did not provide secure nesting habitat and may have allowed increased predation; (b) loss of critical winter habitat with the inundation of deciduous trees and shrubs by Lake Koocanusa; (c) low soil moisture during the 1970s may have contributed to reduced amounts of residual cover for nesting habitat and resulted in low production of grouse and; (d) extensive use of pesticides may have impacted the amount of insects available for food during the brood rearing period.

Based on the research completed the following recommendations are made:

1. Protect the active lek. 
2. Continue the augmentation efforts.

3. Develop land use management agreements with landowners willing to protect grouse habitat.

4. Protect and/or enhance winter habitat.

5. Identify critical nesting and brood rearing habitat.

6. Continue to ensure coordination between the various parties interested in Columbian sharp-tailed grouse management and identify areas for cooperation.

Current Efforts to Develop Protection Strategies on the Tobacco Plains

Based on the recommendations we decided to pursue identifying the most critical habitats to protect in order to maintain the sharp-tailed grouse population. A contract was negotiated with Montana State University to fund a Master's degree student to conduct the research. The Master's program provided an efficient and cost-effective way to obtain the necessary information.

The graduate student project was initiated on March 15, 1990. Specific objectives of the project include:

1. Determine the period of adjustment to radio-marking and transplanting for sharp-tailed grouse on the Tobacco Plains.

2. Determine the use of seasonal habitats in relation to the availability of these habitats.

3. Document nesting success, brood survival, and fall recruitment of grouse.

4. Develop management recommendations for the protection and/or enhancement of grouse habitat on the Tobacco Plains.

Findings from this study will be used to develop a management program for Columbian sharp-tailed grouse in northwestern Montana. This program will emphasize maintaining and enhancing Columbian sharp-tailed grouse habitat on the Tobacco Plains. Results of this study will be used to focus habitat protection strategies on the most critical and limited habitats necessary for the survival of the population. Recommendations and guidelines will provide MDFWP with the tools to develop a sound management program on private and publicly owned lands.

\section{Recommendations for Future Actions}

1. Protection of known critical habitat for the grouse should proceed immediately. The site that contains the only remaining lek is currently for sale as a result of foreclosure proceedings. It is imperative that this site be protected from a change in ownership that may result in habitat degradation.

2. A comprehensive management plan should be drafted for the Tobacco Valley sharp-tailed grouse population. This plan should incorporate the results of Tim Manley's report and the graduate student project and identify the critical habitats requiring protection and/or enhancement. The management plan will also address the population size objectives and outline the augmentation schedule. Areas where conservation easements, agreements to enhance grassland or riparian habitat, and state land leases will be identified. Management responsibilities and the roles of various cooperators will be addressed. 
TERRESTRIAL FURBEARER PROGRAM

Introduction

The Council's Fish and Wildlife Program authorized BPA to fund projects to protect 11,050 acres of habitat for terrestrial furbearers. The Program further specified that protection strategies would involve cooperative agreements with state and federal agencies and private landowners on selected old-growth stands. the mitigation plans identified the need to manage large blocks of habitat for pine marten and lynx. The plan also recognized that managing large blocks of habitat would necessitate cooperative agreements on areas where large block management could occur.

The objective of this advanced design phase was to determine the feasibility of developing management agreements with the Department of State Lands (DSL). The intent was to investigate the concept that management agreements could be developed to protect selected old-growth forest. The first part of the assessment involves determining whether there is even an opportunity to pursue such agreements. The second part involves outlining the process to achieve such agreements.

Summary of Opportunities with the Department of State Lands

The mitigation plan for Hungry Horse identified the potential for habitat protection on areas where large block ownership existed. For that reason, the State Lands parcels were suggested as mitigation sites. The Department of State Lands (DSL) manages two large state forests in northwestern Montana. The Swan State Forest contains 38,912 acres. Over half of that acreage (56 percent) is state owned. Plum Creek Timber Co. is the next largest landholder (27 percent). The remaining ownership is USFS (15 percent) and small private landowners (2 percent) (Montana Department of Natural Resources and Conservation 1978). Currently, a major land trade is being negotiated between state Lands and Plum Creek which would result in a greater amount of state ownership in the Swan Forest.

The Stillwater State Forest is the largest state-owned forest and includes 90,680 acres. The Department of State Lands manages a majority of the land within the boundaries with only minor amounts owned by Plum Creek and small landowners ( $T$. Vars, pers. comm.).

Management guidance on the State Forests are provided by state law and include:

1. Monetary return to state school trust fund;

2. Watershed protection;

3. Management under the multiple use concept.

Overall management direction and approval of individual actions are provided by the Montana Board of Land Commissioners (State Land Board).

The large block of publicly-owned lands provides an opportunity to manage habitat for the benefit of terrestrial furbearers.

Several recent developments indicate the willingness of State Lands to consider proposals for non-timber management on their lands. First, DSL is currently adopting Standard and Guidelines for management of their holdings. These documents replace any existing management plans, Interim Standards and Guidelines have been adopted for grizzly bear, white-tailed deer winter range, and elk in bunchgrass communities. Silviculture Treatment Guidelines are almost completed. DSL is considering developing Standards and Guidelines for snag 
management and old growth forests and have expressed an interest in interagency cooperation in management of old growth forests.

Secondly, the State Land Board recently considered an alternate use of state lands in south-central Montana. A developer wanted to pay DSL not to harvest timber on state lands near a subdivision. The intent was to protect the viewshed. The Department of state Lands required the developer to submit a proposal for State Land Board review. The Department of State Land's economist provided a financial analysis of the proposal. The scenic rights are considered an alterative use of state Lands and must be evaluated against the State's planned management for timber production. The state must receive as much compensation for scenic rights as would be expected from growing and harvesting timber to meet the trust objective. The financial analysis (Appendix H) provided an estimate of the scenic values which would be used to compensate the school trust.

The State Land Board denied the request for a scenic easement on the Bear Creek Canyon site. Reasons for the denial involved the lack of an Environmental Impact Study on the new alternative, the existing management plan specified timber production, and that the monies were not raised by the developer (J. Yahnkey, personal communication). The Board did state, however, a willingness to consider other similar proposals.

Lastly, the local Northwestern Field Office of DSL recently negotiated a lease agreement with a private landowner in the Swan Valley which prohibits timber harvest on State Lands. The private landowner (Soup Creek Ranch) wished to protect the scenic values next to his property by prohibiting timber harvest on the adjacent State Land. The agreement (Appendix I) specified the amount necessary to reimburse the school trust on a per acre annual basis. The Department of State Lands determined that $\$ 60$ per acre per year was required on a ten-year lease.

These examples demonstrate the potential to pursue management options on State Land which will enhance furbearer habitat and still provide the school trust with compensation. In both cases, the alternative of no timber harvest was analyzed; however, with furbearer management, it may be possible to manipulate the existing harvest strategies to improve habitat with only minor financial changes occurring.

Based on these examples and discussions with State Lands personnel, the following steps would be necessary to pursue and agreement:

1. MDFWP submits a proposal to DSL which outlines the intent to compensate the school trust, the areas and acreages involved, and the types of silviculture practices compatible with furbearer management.

2. Cost analysis of the harvest strategies recommended are compared to existing management plans.

3. The type of conveyance (lease or easement) is identified.

4. The completed proposal is submitted to State Land Board for their review.

Prior to submitting a proposal for DSL's consideration, several factors need to be addressed including:

1. Specific management objectives for the target species must be identified and the current status of the target furbearers population must be determined.

2. Timber harvest strategies which are compatible with terrestrial furbearer management need to be identified. 
3. Areas suitable for enhancement must be located.

4. Compare the desired harvest strategy for habitat enhancement to the current management objectives to determine the impact on the school trust.

5. Complete a cost analysis to estimate the amount necessary to compensate the school trust.

6. Further define the administrative steps to complete agreements.

7. Determine if the program is cost effective.

8. Assess the feasibility of the program in view of a possible perceived impact on the local economy. Develop a public involvement process that determines the perceived impact on local industries.

The Department of State Lands has expressed a willingness to pursue agreements with MDFWP to protect important furbearer habitat; however there is concern that designing and analyzing particular timber manipulations for more intensive and specific timber management will be an additional financial and manpower strain on DSL.

Recommendations for Future Actions

1. Establish a multi-agency technical committee to develop in program direction. The committee will identify appropriate biological strategies to protect furbearer habitat and provide coordination with other ongoing programs that are relevant to terrestrial furbearer management.

2. Once areas for habitat protection are identified and specific timber harvest strategies determined, further discussions with State Lands should occur to establish estimated costs and economic impacts of the program. 
PILOT PROJECT - THE ROCKY BAR O RANCH

Introduction

The Rocky Bar 0 Ranch, which includes 2,598 acres, is the largest block of privately owned land along the North Fork of the Flathead River (Figure 3). The property is bounded on the east by Glacier National Park, on the north and south by the Flathead National Forest and on the west by Coal Creek State Forest. The ranch is owned by Tom and Joan Ladenburg as part of the Rocky Bar 0 Corporation and represents 20 percent of all private lands in the North Fork area.

Portions of the ranch are located within the designated Wild and Scenic River Corridor and includes four niles of river frontage, one mile of Coal Creek, and several sections of adjacent low elevation bottom lands.

Besides the exceptional scenic and recreational values, the property has very high values for both wildlife and fishery resources. Three threatened or endangered species are known to occupy the area: grizuly bears, wolves, and bald eagles. The North Fork drainage has been identified a part of the grizzly bear recovery area for the Northern Continental Divide Ecosystem. The only known den for the Rocky Mountain Grey Wolf in the lower 48 states occur across the river in Glacier National Park (Ream et al. 1990). Bald eagles winter in the area and a nest site is located approximately 3 miles to the southeast. Many other species of wildlife use the habitats found within the Rock Bar 0 Ranch, including elk, moose, mule deer, white tailed deer, and numerous non-game species.

Coal Creek provides critical rearing habitat for bull trout as well as a critical migratory route for upstream spawning adults. In addition, this stream also has a documented population of pure strain Westslope cutthroat trout. Both are considered species of special concern by MDFWP and the U.S. Forest Service.

\section{Previous Protection Efforts}

In 1976, the North Fork of the Flathead River was designated as part of the Wild and Scenic River system. Within two years, the Flathead National Forest had developed plans to protect the scenic values along the river. These plans identified the scenic river corridor boundaries and outlined the strategies to protect the scenic values on private lands within the corridor boundaries. Where possible, conservation easements were to be purchased to protect the scenic values on these private lands.

Two of the properties identified in the plan were the Rocky Bar 0 Ranch with 1,000 acres and the adjacent 2,000 acres owned by the Silver Bow Realty Company. In 1979, The Nature Conservancy and the Flathead National Forest became involved in a land exchange for the silver Bow property but the negotiations failed. In 1983, the Ladenburg's purchased the Silver Bow property. The Ladenburg's intended to trade for timber or sell the parcels within the scenic river corridor to the Forest Service and repay the loan.

By 1986, the Forest Service acquired approximately 350 acres south of Coal Creek. Later that year, the limited Land and Water Conservation Funds appropriated by Congress were withdrawn. At the same time, the timber market dropped so further land exchanges were not possible. In 1987, foreclosure action was initiated foreclosure action on the Rocky Bar 0 Ranch. The Nature Conservancy and the Trust for Public Lands attempted to negotiate a complicated plan to protect the property, but funds were not available to complete any of the purchase agreements. During the development of mitigation plans for Hungry Horse and Libby dams, MDFWP was approached by local landowners, the Forest Service, and conservation organizations requesting funding support to secure the property. At that time, no funds were available. 


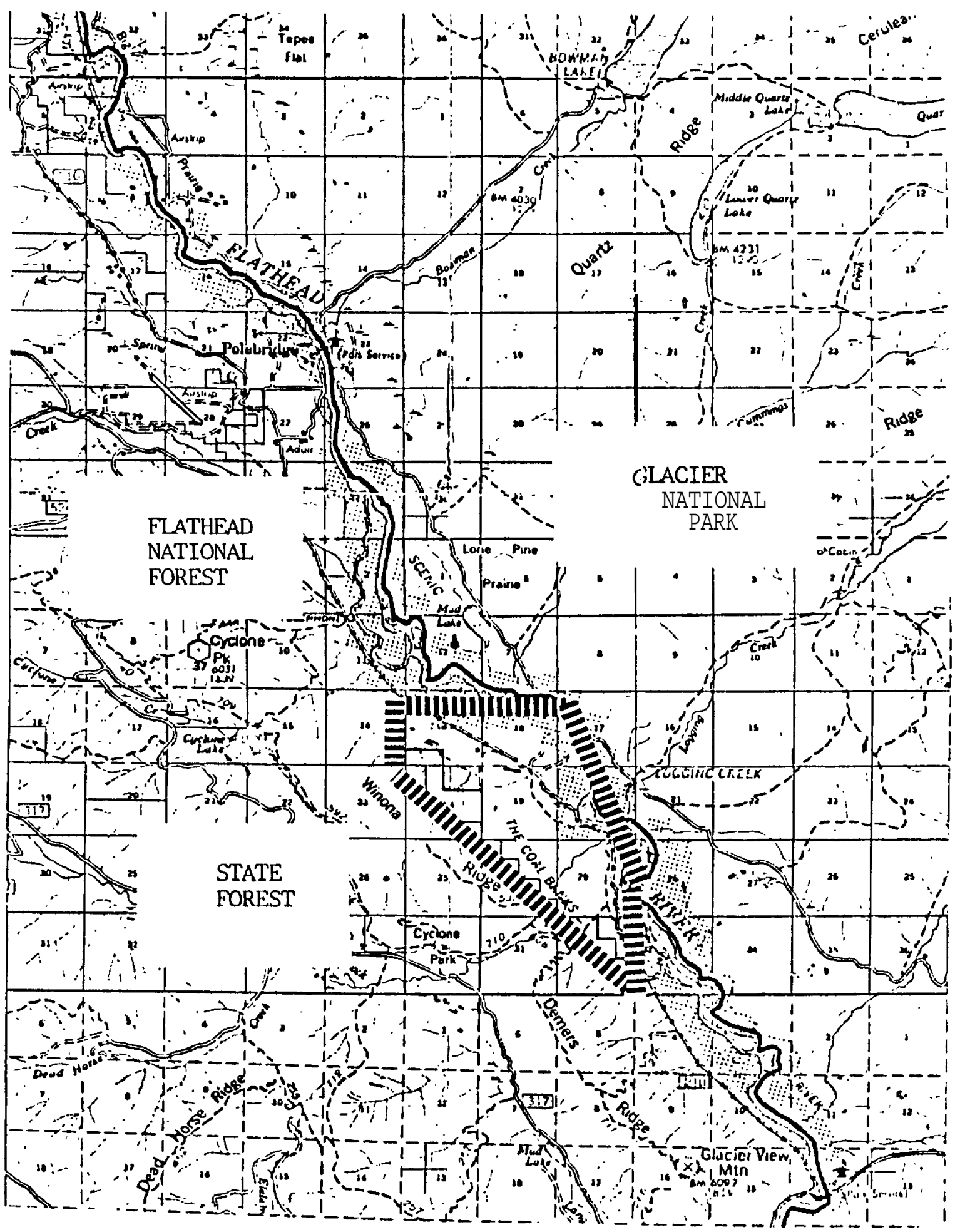

Figure 3. General location of the Rocky Bar 0 Ranch, North Fork of the Flathead River, Montana. 
In the fall 1987, MDFWP was approached by both the landowner and the Flathead National Forest requesting financial assistance to secure conservation easements over portions of the ranch. After initial review it was determined that the potential loss of wildlife habitat by not taking action was great enough to warrant entering into discussions to try and keep the ranch intact.

In January 1988, the Ladenburg's filed for bankruptcy to protect their interests in the property and to allow them some time to develop a reorganization plan. The fate of the land was in question and interest by developers to subdivide the ranch provided the need to act quickly to secure the property. The fate of the Ladenburg property was viewed as a key to future development in the North Fork as it represented 20 percent of all private lands.

This pilot project was established to protect the wildlife and open space values of the Rocky Bar 0 Ranch. The primary objectives were to:

1. Protect habitat to benefit mitigation species including grizzly and black bears.

2 Demonstrate opportunities for cooperative projects with private conservation organizations and federal agencies.

3. Demonstrates the steps required to obtain a conservation easement on private lands and any agreements necessary between cooperative entities.

Summary of Current Protection Efforts

The primary objective of the protection plan was to protect the most critical wildlife habitat by fee-title acquisitions or conservation easements. The core areas identified included the bottomlands along the Flathead River and east of the North Fork road, and the riparian areas associated with Coal creek. The uplands adjacent to Coal Creek were also considered important to the integrity of the protection plan.

A complex purchase agreement was developed which identified the specific parcels to be acquired by fee-title, conservation easements or land exchange. Table 3 summarizes the acreage of wildlife habitat protection, the type of instrument, and the acquiring entity. The acreage figures reflect all land transactions to date on the Rocky Bar 0 Ranch, including purchases made by the Forest Service prior to the 1988 purchase agreement.

Conservation easements were acquired on approximately 512 acres of floodplain habitat adjacent to the North Fork of the Flathead River. The basic scenic easement format had been tentatively agreed to by the Forest Service and the landowner when the federal funds were frozen. Similar easements have been conveyed on several other private parcels within the Wild and Scenic River boundary. These documents typically place restrictions on types of developments which may affect the scenic values on private property along a designated Wild and Scenic River. However, in order for MDFWP to support acquiring an easement with mitigation funds, the scenic easement was modified to include restrictions to protect grizzly and black bear habitat (Appendix I).

Specific conditions added to the scenic easement prohibited:

1. Further subdivision of the property;

2 Boneyards of dead domestic animals;

3: Keeping of some types of domestic livestock such as pigs, sheep, and goats;

4. Beehives;

5. Filling or draining of wetland areas. 
Table 3. Summary of wildlife habitat protected on the Rocky Bar 0 Ranch.

PROTECTION TOOT,

Fee Purchase

Conservation Easements

Additional Easements

Assoc. with Project
ACREAGE

216 acres south of

coal Creek

132 acres south of

Coal Creek

234 acres Coal Creek

582 acres total

408 acres Flathead River

54 acres Flathead River

50 acres Flathead River

512 acres total

\section{1,094 acres total protected}

COOPERATOR

$1984 \quad \$ 380,000$ USFS

$1986 \quad \$ 231,500$ USFS

1988 \$495,000 Conservation (exch.value) Buyer

$\begin{array}{ll}1988 & \$ 400,000 \mathrm{BPA} \\ 1988 & \$ 52,500 \text { USFS } \\ 1988 & \begin{array}{l}\text { Exchange of USFS } \\ 160 \text { acres benchlands }\end{array}\end{array}$

640 acres Lindberg Lake

1988
Conservation buyer exchanged for Coal Creek parcel 
The conservation easements were purchased with a combination of BPA funds Forest Service funds and exchange for Flathead National Forest lands (Table 3).

All conservation easements will be administered by the U.S. Forest Service. An administrative plan was cooperatively developed by the Flathead National Forest MDFWP, and the Ladenburgs. The plan is on file in the Flathead National Fores; Supervisor's Office.

The objectives of the administrative plan are:

1. To describe the existing uses of the land and rights retained by the landowner that are compatible with the intent of the easement.

2. To document the existing biological and physical conditions as a baseline for monitoring future changes.

3. To describe the important wildlife values protected by the easement.

4. To prescribe management guidelines for enhancing wildlife values on the easement area.

5. To outline the procedure for administering the easement.

A total of 582 acres was purchased in fee (Table 3). Of that total the Forest Service purchased 348 acres in 1984 and 1986 using Land and Water donservation funds. In 1988, a conservation buyer purchased 234 acres along the mouth of Coal creek. This parcel was ultimately transferred to the Forest Service in exchange for 640 acres of national forest lands in the Swan Valley. This section of land was encumbered by a conservation easement before the exchange was completed. This easement prohibited further development and also contained restrictions to protect grizzly bear habitat, wetlands, and white-tailed deer summer range.

Summary of the Protection Process for the Rocky Bar 0 Ranch

The following summarizes the actions necessary to develop and implement complete a protection plan for the Rocky Bar 0 Ranch:

1. Field Review/Biological Assessment

Field review to determine existing wildlife benefits and habitat values, and identification of easement restriction conditions necessary to protect those values.

2. Identification of Priority Areas

Identified areas necessary to protect critical habitat values for target wildife species.

3. Draft Easement Document

Develop a conservation easement acceptable to USFS, MDFWP, and the landowner.

4. Purchase Agreement

Develop a purchase agreement that identifies the parcels involved, the estimated costs, and the type of protection tool.

5. Coordination with Conservation Organizations During initial negotiations with landowners, met with the Trust for Public Lands, Flathead Land Trust, and The Nature Conservancy to coordinate cooperative actions. 
6. Negotiate Purchase Conditions

Negotiations held between -landowners, Flathead National Forest, MDFWP, Whitefish-Credit Union, and the bankruptcy court.

7. Coordinate with the Wildlife Mitigation Project first recommended during mitigation planning 1986. Reviewed by Advisory Committee in spring 1988. Proposal developed and submitted to BPA for funding.

8. Purchase Administration

Obtain legal descriptions, title reports, surveys, and appraisals.

9. Interagenc y Agreements

Develop agreements between U.S. Forest Service and BPA to acquire and administer easements.

10. Administrative Plan

Draft an administrative plan in cooperation with U.S. Forest Service, MDFWP, and the landowners to document baseline information on current land use and conditions, further define easement intent, and outline the monitoring requirements.

11. Public Involvement

Meet with agencies and organizations including county commissioner, North Fork Inter-local Association, Chamber of Commerce, and service clubs.

Summary of Habitat Protected

A total of 1,094 acres of wildlife habitat on the Rocky Bar 0 Ranch was protected using a variety of protection strategies (easements, fee purchase, exchanges). It is important to note that any protection on the ranch required the involvement of the mitigation program and the conservation buyer. These commitments allowed the U.S. Forest Service to proceed with a purchase plan approved by the bankruptcy court with only limited Forest Service funds.

This project also demonstrated the levels of cooperation possible on mitigation projects. Mitigation funds were used only on direct acquisition of a conservation easement to protect critical wildlife habitat. The U.S. Forest Service provided funds to complete all the acquisition costs including title reports, land surveys, and appraisals.

In addition, as a result of re-programmed funds for the Rocky Bar 0 Ranch, the Flathead National Forest was able to purchase an additional 1,537 acres with significant scenic and wildlife values along the North Fork Flathead River (M. Conner, pers. conun.). The 1,537 acres of additional land acquired with the reprogrammed Rocky Bar 0 funds cost $\$ 1,456,000$. Federal funds were appropriated to complete purchases along Coal Creek; however, the U.S. Forest Service and the Ladenburgs were not able to reach agreement on the purchase price. To fulfill the obligation in the Interagency Agreement with BPA, the Flathead Forest requested the available funds be re-programmed to acquire the next largest ranch on the North Fork. These lands are outside the Wild and Scenic Corridor but contain valuable wildlife habitat and will add to habitat protection for grizzly and black bears. 
Program Approach

Habitat preservation was identified as the highest priority objective in the Department's statewide habitat plan (MDF'WP 1989). Habitat preservation is necessary to provide adequate land base for wildlife. Many wildlife use a mix of both public and private lands and only proper stewardship on these lands will ensure long-term use by wildlife.

The goal of the Northwest Montana Wildlife Mitigation Habitat Protection Project is to develop programs preserving important wildlife habitat as mitigation for lands flooded by Hungry Horse and Libby dams. The programs will utilize two basic approaches: (1) protecting and/or-enhancing wildlife habitat on private, or in some cases, public lands; or (2) direct acquisition of critical habitat. Habitat protection will be achievedby a number of different strategies: however, the primary tools used will include conservation easements or fee-title acquisitions.

Each protection project will be examined on a case-by-case basis to determine the appropriate protection tool. In general, the distinction between proceeding with a conservation easement or a direct acquisition will be determined by the following criteria:

1. Landowner desires;

2. Degree of critical importance of a particular tract;

3. Intensity of management required, and;

4. Type and abundance of benefits achieved.

Typically, habitat protectionefforts have focusedon serendipitous opportunities that are presented to agencies. Opportunities to acquire lands, often presented by landowners themselves, are more numerous than funding possibilities, This results in protection efforts based on reactions to situations as they arise With the mitigation program, we will be "pro-active" instead of "reactive." Technical committees identify critical areas for protection and specific goals for individual species or species groups. The purpose of the process is to focus efforts on key, critical habitats and developing reasonable cost-effective projects.

\section{Financial Considerations}

Estimations of short- and long-term program costs are difficult to make due to the wide range of protection strategies and cooperative opportunities available. However, it is appropriate to consider general costs and to itemize certain expected costs.

Habitat protection costs involve four areas: (1) protection tool (easement, acquisition, lease): (2) administration; (3) enhancement, and; (4) management. Protection costs include the actual amount of funds used to acquire the necessary level of protection. Costs may range from no funds involved, in the case of donated properties or easement to fee title acquisition, on a cost per acre basis. The following estimations are listed to provide guidelines only.

\section{$\underline{\text { Protection Costs }}$}

Fee-Title Acquisitions

Waterfowl Projects

Lake county

$\$ 400-800 /$ acre 
Flathead County

Bear Projects

North Fork (uplands)

Middle Fork

Swan Valley

Sharptail Projects

Tobacco Plains
$\$ 1,000-1,500 /$ acre $\$ 3,000-5,000 /$ acre

$\$ 1,000-3,000 /$ acre

$\$ 800-1,500 /$ acre

$\$ 350 \cdot$ Boo/acre

Conservation Easements

Easement costs are difficult to estimate because each easement value is based on the number and types of restrictions. Easement values are determined based on the difference of the appraised values with and without the easement conditions (Small 1988; Diehl and Barrett 1988; NTHP and The Land Exchange 1984).

Examples:

Copper Creek Conserve

Rocky Bar 0 Ranch

USFS Scenic Easements

donated

$50 \%$ of fee value

30 - 50\% range of fee value

Administrative Costs

Easement or Fee Acquisitions

Appraisals

$\$ 2,000-4,000$

Depends on acreage and complexity of easement conditions. Easement appraisals are generally more expensive because they typically involve two separate evaluations (before and after).

Recording Fees

$\$ 5 /$ page

Fee Title Acquisitions Only

Title Policy

Closing Fees

Survey of new boundaries

Feasibility reports

$\$ 300 \cdot 500$

$\$ 2,000 \cdot 8,000$

Major wetland enhancement projects my require detailed soil or hydrological surveys.

\section{Easements only}

Easement Documentation Report

$\$ 2,000 \cdot 3,000$

Biological evaluation and baseline information, required by IRS if landowner clai ns tax deductions. 
Riparian/Wetland Project Examples

Fencing

Shrub planting

Diking

Island construction
$\$ 4,000 / \mathrm{mile}$ (includes labor) $\$ 1,700 / \mathrm{mile}$ (materials only)

$\$ 1 /$ seeding

$\$ 100,000-400,000 / \mathrm{mile}$

$\$ 9,000 /$ acre

\section{Management Costs}

Fee Title Acquisitions

Long-term management costs vary depending on individual projects, but generally match or exceed the initial purchase amount.

Conservation Easements $\quad \$ 1,500$ or 5 to $10 \%$ easement value

Easement monitoring is required at least annually to inspect property and discuss problems with landowner. Does not include legal fees if problem arises.

Summary of Activities Necessary to Complete Habitat Protection

The following list provides a framework of activities necessary to implement a protection project, These steps are completed after a proposed project has been approved for action.

1. Field review and biological assessment:

Identify critical sites or core areas to be protected and any special management needs or easement conditions.

2. Obtain legal descriptions and maps of property.

3. Develop list of wildlife benefits, acreage involved and other values.

4. Identify environmental requirements:

Permits.

5. Obtain specific acquisition information:

Warranty deeds, water rights, land uses, comparable sales, title surveys.

6. Identify cooperators and obtain commitments.

7. Facilitate cooperators involvement:

Develop project proposals and permits, provide local coordination.

8. Identify potentially affected interests and coordinate activities.

9. Develop recommendations for managing/monitoring the protected habitats. 


\section{REFERENCES}

Becker, D. Wildlife Biologist, Bureau of Indian Affairs, Ronan, Montana. Personal communication, March 1988.

Bissell, G. N. and C. A. Yde. 1985. Wildlife and wildlife habitat mitigation plan for Hungry Horse hydroelectric project. Montana Dept. of Fish, Wildlife and Parks, Kalispell. $46 \mathrm{pp}$.

Bleiker, H. and A. Bleiker. 1986. Citizen Participation Handbook for Public Officials and Other Professionals Serving the Public. Institute for Participatory Management and Planning. Laramie, Wyoming.

Brown, J. Wildlife Biologist, Montana Dept. of Fish, Wildlife and Parks, Libby. Personal communication, March 1990.

Conner, M. Forester, Flathead National Forest, Supervisor's Office, Kalispell, Montana. Personal communication, My 1990.

Cross, J. Region One Wildlife Manager, Montana Dept. of Fish, Wildlife and Parks, Kalispell, Montana. Personal communication, February 1990.

Diehl, J. and T. S. Barrett. 1988. The Conservation Easement Handbook. The Land Trust Exchange, Alexandria, Virginia. 269 pp.

Dood, A. R., R. D. Brannon and R. D. Mace. 1985. Draft Programmatic Environmental Impact Statement--The Grizzly Bear in Northwestern Montana. Montana Dept. of Fish, Wildlife and Parks, Helena, Montana. 259 pp.

Hall, B., Protection Planner and Director of Stewardship, The Nature Conservancy, Helena, Montana. Personal communication, August 31, 1989 and September 6, 1989.

Johnkel, C. 1983. Grizzly bear critical sites. Border Grizzly Project, Special Report 69. University of Montana, Missoula.

Montana Dept. of Fish, Wildlife and Parks. 1984. Conservation Easement Guidelines, Unpublished report, Helena, Montana.

1989. Draft Lands Priority Process and Statewide Habitat Plan. Helena, Montana.

Montana Power Company. 1990. Kerr Project--Mitigation and Management Plan. Butte, Montana. $110 \mathrm{pp}$.

National Trust for Historic Preservation and The Land Trust Exchange. 1984. Appraising easements. The Preservation Press, Washington, D.C. 68 PP.

Null, H., Assistant Manager, National Bison Range, U.S. Fish and Wildlife Service, Moiese, Montana. November 24, 1987.

Mundinger, J. and C. Yde. 1984. Wildlife and wildlife habitat mitigation plan for Libby hydroelectric project. Montana Dept. of Fish, Wildlife and Parks, Kalispell, Montana. PP.

Ream, R. R., D. H. Pletscher, D. K. Boyd, and M. W. Fairchild. 1990. Wolf Ecolocy Project. Quarterly Progress Report, March through May 1990. School of Forestry, Univers lty of Montana, Missoula. 2 PP. 
Small, S. J. 1988. Preserving Family Lands--A Landowner's Introduction to Tax Issues and Other Considerations. Powers and Hall Professional Corporation, Boston, Mass. 47 PP.

Summerfield, B. 1986. Bull River private lands evaluation for grizzly bear habitat. Memorandum to file \#2670. Kootenai National Forest, Libby, Montana.

U.S. Department of Agriculture. 1978. Acquistion plan for private lands within the Flathead Wild and Scenic River Corridor. Unpublished report. Supervisor's Office, Flathead National Forest, Kalispell, Montana. 83 pp.

U.S. Department of the Interior. 1983. Grizzly Bear Recovery Plan. U.S. Fish and Wildlife Service, Denver, Colorado. $195 \mathrm{pp}$.

, 1987. Draft Environmental Assessment--Grizzly Bear Population Augmentation Test, Cabinet-Yaak Ecosystem. U.S. Fish and Wildlife Service, Missoula, Montana. 65 PP.

U.S. Department of the Interior, Canadian Wildlife Service, and Environment Canada.. 1986 . North American Waterfowl Management Plan. 19 PP.

Vars, T. Manager, Swan State Forest, Department of State Lands, Condon, Montana. Personal communication, April 1990.

Wood, M. 1990. The Ashley Creek Waterfowl Project. Montana Dept. of Fish, Wildlife and Parks, Kalispell, Montana. In preparation.

Yahnkey, J. Bureau Chief, Timber Management, Department of State Lands, Missoula, Montana. Personal communication, October 5, 1989. 
APPENDIX A

General proposal format for habitat protection projects. 
I. Introduction

A. Narrative description of why the project is needed and how it fits the mitigation program, and why mitigation funds are required.

B. Statement assessing what happens if the project is not funded or pursued.

C. Identification of other resource values and recreational benefits.

II. Project Overview

A. Narrative summary of the intent of the project, area involved, and existing land use and landownership.

B. Location map of the area.

III. Project Proposal

A. Identification of core parcels, landowners, and number of acres.

B. Explanation of type of protection tool necessary (fee-title acquisition, conservation easements, lease).

C. Summary of development or enhancement measures proposed.

IV. Biological Benefits

A. Narrative summary of expected benefits for target wildlife species.

B. Identification of other species benefits.

V. Management Responsibilities/Cooperators

A. Identification of entity responsible for long-term management.

B. Identification of any cooperators in the project and their role.

VI. Estimated Costs

A. List of project costs including acquisition and administrative costs (appraisals, title reports, documentation reports).

B. Identify entities responsible for specific costs.

VII. Special Considerations/Management Implications

A. Narrative description of any factors that should be considered in the actual purchase of the property on the long-term management (taxes, game damage, increased manpower needs).

B. List of all required permits or environmental assessments (water rights, 404 permits. 
APPENDIX B

Waterfowl/Wetland project evaluation form to review potential waterfowl projects. 
Area Name/No.

Score: $E^{*}$

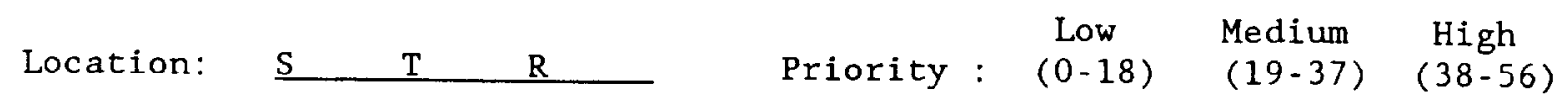

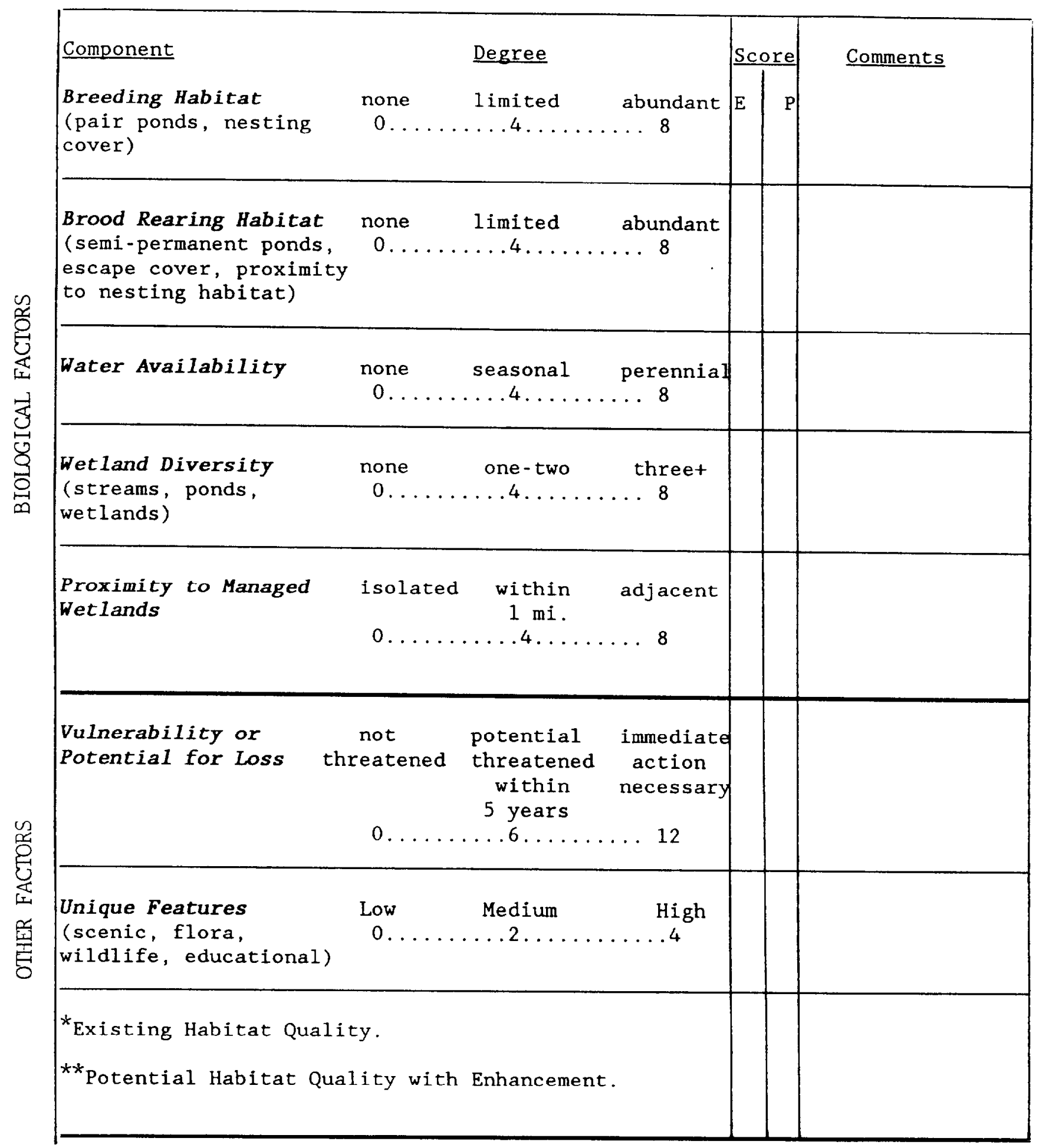


APPENDIX C

Current format for management plans on MDFWP Wildlife Management Areas. 


\section{Introduction}

2. Statement of Purpose. An EXAMPLE is the statement from the Blackfoot-Clearwater: "The WMA was purchased primarily to provide elk winter range and alleviate fall-winter-spring elk depredations on private lands. Secondarily, the WMA was purchased to provide white-tailed and mule deer winter ranges."

2a. Add what dollars purchased the area in proper percentage, i.e.,

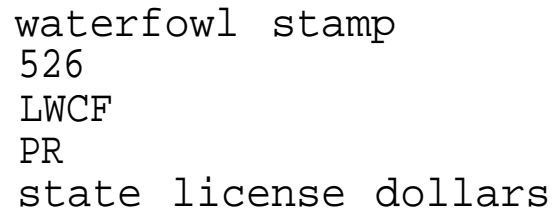

? State objectives as listed in federal aid document (if there is one).

B. GOALS, OBJECTIVES, PROBLEMS AND STRATEGIES

This is the most important section of the management plan. Everything evolves around what is decided here. EXAMPLE BELOW.

Prioritize objectives and strategies: WMA objectives must be shown to mesh with species plans and the strateqic plan. Land acquisition and management is a strategy to meet stated objectives in the species plan and strategic plan.

SET A DATE FOR WHEN EACH STRATEGY IS TO BE ACCOMPLISHED

Goal: To fulfill as much of region's portion of the department's elk, deer, antelope, upland bird, nongame and waterfowl strategic plan objective as good land stewardship allows.

Objective 1. Practice proper land stewardship which means managing for the maximum diversity of vegetation communities toward a state of climax: or managing for potential natural vegetation as designated by soil types.

Problem 1. overgrazing, uneven grazing distribution, soil erosion

Problem 2. weeds

Problem 3. no knowledge of what is going on with plant succession 


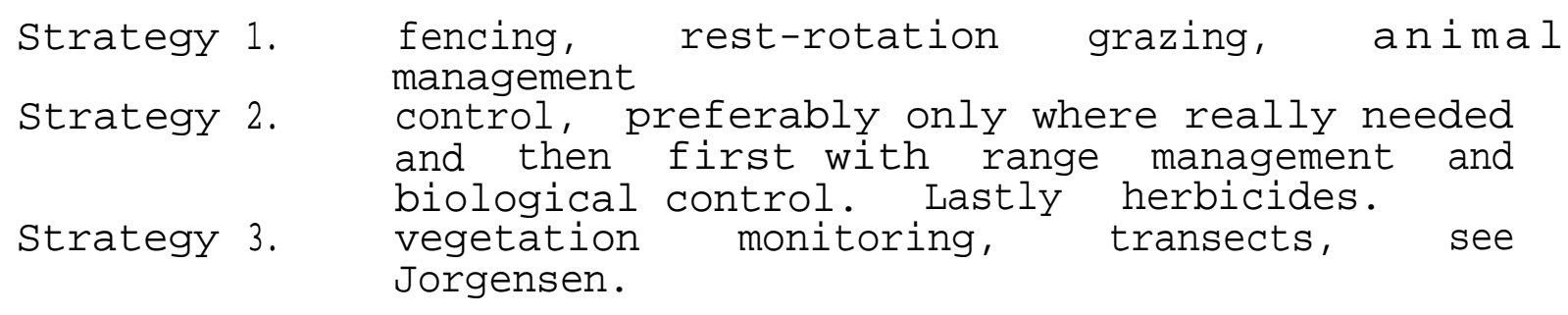

Objective 2. Harvest $X$ number of $X$ species which is $X$ percentage of the region's objective.

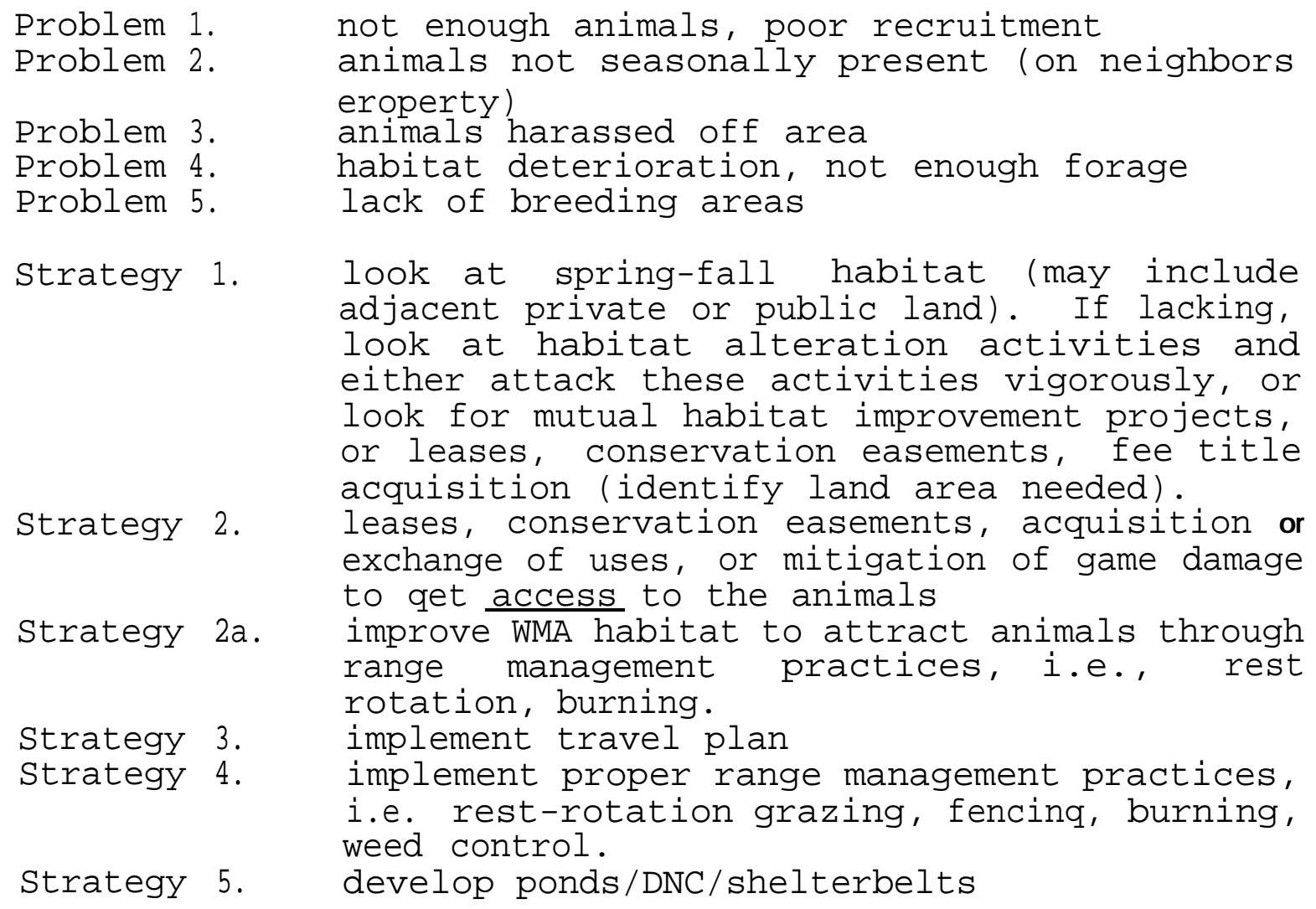

Objective 3. Provide X number of hunter days for elk, X number for deer and $X$ number for waterfowl at $X$ percentage success rate which is $X$ percentage of the region's objective.

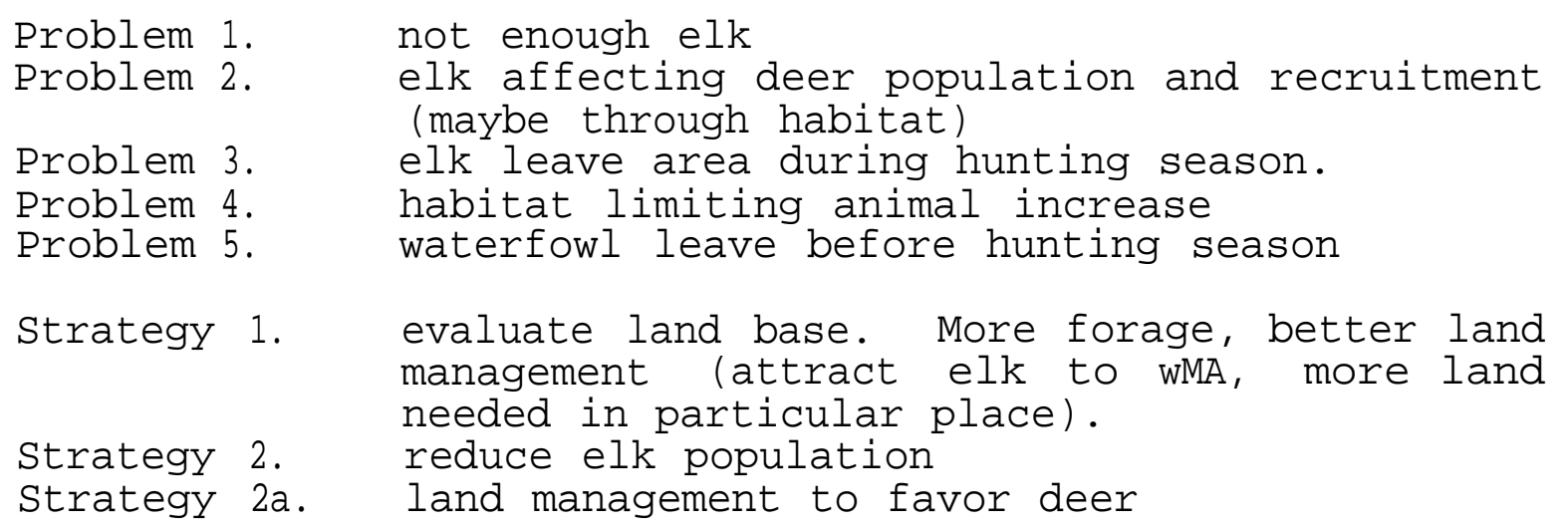




\begin{tabular}{|c|c|c|}
\hline Strategy & 3. & provide more security cover \\
\hline Strategy & $3 a$. & change hunting season \\
\hline Strategy & $3 b$. & $\begin{array}{l}\text { agreement with neighbor who has security cover } \\
\text { to maintain this habitat type }\end{array}$ \\
\hline Strategy & 4 . & $\begin{array}{l}\text { develop land management projects to increase } \\
\text { necessary habitat components }\end{array}$ \\
\hline Strategy & $4 a$. & $\begin{array}{l}\text { obtain more habitat through leases, } \\
\text { conservation easements, fee title }\end{array}$ \\
\hline Strategy & & provide attractants to keep \\
\hline Strategy & & harassment \\
\hline
\end{tabular}

Objective 4. Produce $X$ number of breeding Paris/X number of wintering animals, which is $X$ percentage of the reqion's objective.

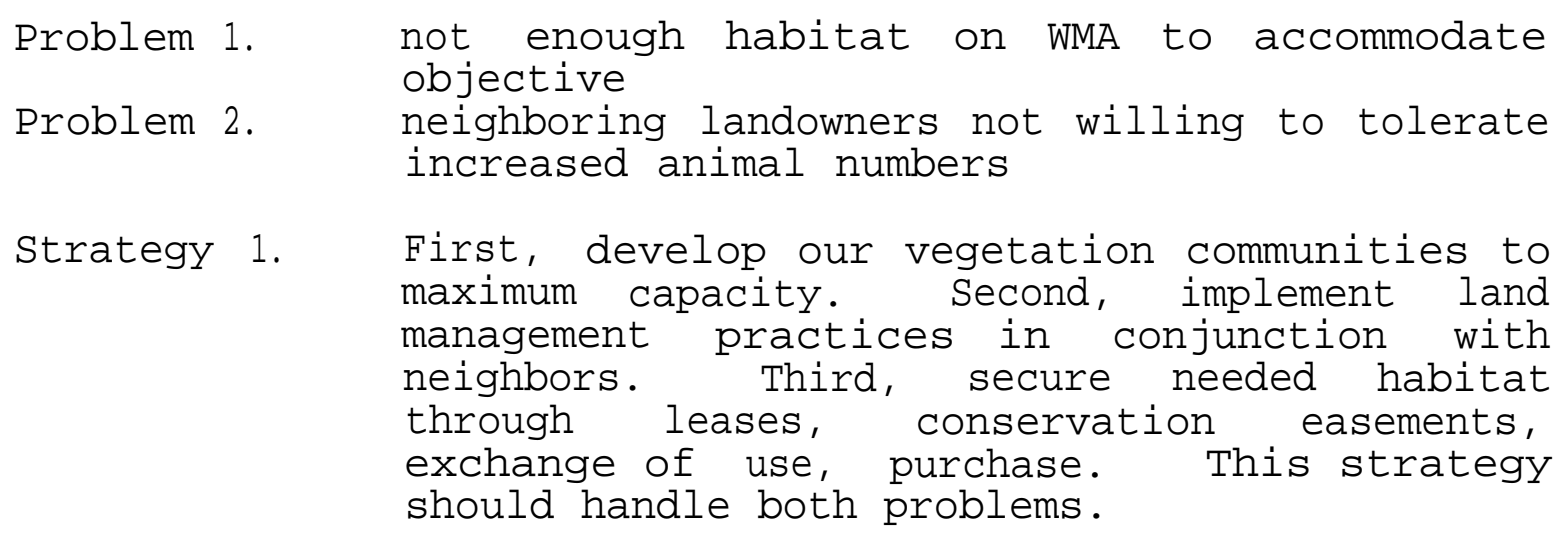

\section{MONITORING: AN EXPLANATION}

The annual work plan will be a yearly addendum to the management plan. The work plan uses strategies that are in the management plan and develops projects that will solve stated objectives. The work plan is the action document that carries out the management plan. This allows us to see what we set out to accomplish, and what we did or did not get done. This also allows a new individual to find in one document what the history of the WMA was, where we want to go based on our objectives, where we are headed, and how much we have accomplished. Items monitored should be the work plan projects to see if they actually worked to solve stated problems which were keeping us from reaching identified objectives. Monitorins the work plan is part of the management plan.

Ask yourself, did the strategies allow us to meet the objective? If not, why not? What other strategies must be put in place to fulfill the objective? This is why the management plan is flexible and will constantly change. It keeps us working on stated objectives. These objectives change as we meet our objectives and set new ones. Of course, some objectives are very long term, but each year the amount of progress made must be recorded.

Work plans project layout (at beginning of year) and completion report (at end of year) will be included in the management plan as Appendix F. 
APPENDIX A: HISTORY

When we bought it, how much, what are the past and present use/activities. History of problems and what was done to solve them. Land management practices. Real or potential impact to adjacent lands and landowners and how to address such impacts.

\section{APPENDIX B: PHYSICAL DESCRIPTION}

Include vegetation communities: and vegetation transects (location and data): climate: qeology/topography; surface/mineral ownership: water rights; legal description of areas owned/eased/easement; structure i.e. buildings, fences, bridges, culverts, water impoundments, signs and boundary marker, public use facilities (these recorded on aerial photos or Xerox copies of).

Real or potential impacts to adjacent lands and landowners and how to address such impact.

\section{APPENDIX C: WILDLIFE DATA}

Wildlife distribution, densities and use by season and by species (record distribution on map/photos).

Real or potential impacts to adjacent lands and landowners and how to address such impact.

\section{APPENDIX D: TRAVEL PLAN}

Transportation network (travel plan) on the WMA, including public access points, road closures when and why. (Map showing open/closed roads).

Also rules and regulations for the WMA

( $t$ his appendix should stand alone as a map on one side and requlations to be used as a handout to the public).

Real or potential impacts to adjacent lands and landowners and how to address such impact.

\section{APPENDIX E: LEASES}

copy of agricultural leases; oil and gas leases; any other leases: and procedures for setting leases, if any.

Real or potential impacts to adjacent lands and landowners and how to address such impact. 
APPENDIX F: WORK PLANS

Annual work plans (project description and completion reports).

Real or potential impacts to adjacent lands and landowners and how to address such impact.

ftm

601.8 
APPENDIX D

Bear Habitat Protection Site Evaluation form to rank potential projects. 
Area Name:

Score:

Location: $\mathrm{S} \mathrm{T}$ Priority:

Commponent

$\underline{\text { Ranking }}$

Rating

Habitat Quality

Low: $\quad 0-33 \%$ coverage

Medium: $34-66 \%$ coverage

High: $\quad 67-100 \%$ coverage

3

Comments:

Bear Use

None

0

Seasonal

5

Year-round

Comments:

Size of Tract

1 point for each 10 acres

Comments :

Existing Human Influence

None or Limited

Primitive Road

0

County/Forest Road

Highway

Resident/Business

Comments:

Development Potential

None

Agriculture (livestock, crops)

Recreation (concentrated)

Road/Timber Harvest

Residential Subdivision

Comments:

Adjacent Land Use

Provides secure habitat

Management Compatible

5

Limited Development

$-5$

Extensive Development 
APPENDIX E

The Copper Creek conservation easement.

$\mathrm{E}-1$ 
DEED OF CONSERVATION EASEMENT

THIS GRANT DEED OF CONSERVATION EASEMENT by Copper Creek Conserve, Incorporated, whose address is 120 w. Sixth Street, Libby, Montana 59923 (hereinafter referred to as "Grantor"), and THE NATURE CONSERVANCY, a District of Columbia nonprofit corporation with its principal offices at 1815 North Lynn Street, Arlington, Virginia 22209 (hereinafter referred to as the "Conservancy" ),

\section{WITNESSETH THAT:}

WHEREAS, Grantor is the owner of certain real property in Sanders County, Montana, consisting of 107 acres, more or less, more particularly described in Exhibit $A$ attached hereto and incorporated herein by this reference (hereinafter referred to as the "Property"); and

WHEREAS, the Property is surrounded by the Kootenai National Forest and within one mile of the Cabinet Mountains Wilderness Area, has significant ecological and open space values as defined in Section 76-6-104, Montana Code Annotated (MCA), and provides significant relatively natural habitat for native plants and wildlife, including forest and riparian habitat for grizzly bear, black bear, fisher, and other game and nongame species; and

WHEREAS, protection of the Property will contribute to the ecological integrity of the west slope of the Cabinet Mountains, conserve significant relatively natural habitat for wildife and plants, and aid in efforts to recover grizzly bear and fisher populations in the Cabinet-Yaak ecosystem; and 
WHEREAS, all of these natural elements and ecological values are of great importance to Grantor and to the people of the state of Montana, and are worthy of preservation; and

WHEREAS, Grantor, as owner of the Property, owns the affirmative rights to identify, preserve, and protect in perpetuity its open space character and its significant relatively natural features and values; and

WHEREAS, the Conservancy is organized to preserve and protect natural areas and ecologically significant land for scientific, charitable, and educational purposes: and

WHEREAS, the State of Montana has recognized the importance of private efforts toward preservation of natural systems in the state by enactment of Section 76-6-201, et seq., MCA; and

WHEREAS, the Conservancy is a private organization qualified under the terms of Sections 76-6-104(5) and 76-6-204, MCA, and under Section 170 (h) (3) of the Internal Revenue Code of 1954, as amended, to acquire and hold conservation easements;

NOW, THEREFORE, in consideration of the mutual covenants contained herein, based upon the Common Law, and further, pursuant to Section 76-6-201, et seq., MCA, Grantor hereby conveys to the Conservancy, its successors and assigns, a perpetual Conservation Easement (hereinafter referred to as the "Easement") consisting of the rights and restrictions hereinafter enumerated, over and across the Property.

A. Purposes. It is the purpose of the Easement to preserve and protect in perpetuity and, in the event of their degradation or destruction, to enhance and restore the open space and 
significant relatively natural features and values of the Property. It is further the specific purpose of this Easement to conserve important habitat for grizzly bears and fishers, to protect rare or unique native plants currently known or later identified, and to conserve the diverse riparian and forest vegetative communities and the wildlife inhabiting these communities. In achieving these purposes, it is the intent of the Easement to permit the continuation of such uses of the Property as may be conducted consistent with the conservation values protected herein.

Pursuant to the terms of Section 76-6-107, MCA, the Property preserved hereby as natural land may not be converted or directed to any uses other than those provided herein.

B. Easement Documentation Report. Competent naturalists familiar with the Property have prepared a collection of baseline data on the Property and its resources. The data and explanatory text are presented in the "Copper Gulch Conservation Easement Documentation Report", prepared by Western Technology and Engineering, Inc., of Helena, Montana, and dated September 1990. A copy of the report is on file with both Grantor and the Conservancy and by this reference made a part hereof. The parties acknowledge that the report is intended to establish the condition of the Property subject to the Easement as of the date written above and that both Grantor and the Conservancy have acknowledged in a signed statement (Exhibit B) that the report accurately represents the condition of the Property at the time of conveyance, in accordance with Treasury Regulation Section 1.170A-14 (g) (5) (i).

The parties agree that, in the event a controversy arises with respect to the nature and extent of the biological or physical condition of the Property, the parties shall not be foreclosed from utilizing all other relevant or material documents, surveys, reports, and other information to assist in the resolution of the controversy. 
c. Rights of the Conservancy. The rights conveyed to the Conservancy by the Easement are the following:

1. To identify, to preserve and protect in perpetuity, and in the event of their degradation or destruction to restore the open space and significant relatively natural ecological features and values of the Property.

2. To enter upon the Property to enforce the rights herein granted, to study and make scientific observations of its ecosystems, and to determine that Grantor's activities are in compliance with the terms of the Easement, all upon prior notice to Grantor and in a manner that does not unreasonably disturb the use of the Property by Grantor consistent with the Easement. The Conservancy shall also have the right of immediate entry to the Property if, in its sole judgment, such entry is necessary to prevent damage to or the destruction of the conservation values protected by the Easement.

3. To enjoin any activity on or any use of the Property that is inconsistent with the Easement and to enforce the restoration of such areas or features of the Property as may be damaged by such activities.

D. Consistent Uses of the Property. The following uses and practices by Grantor, though not an exhaustive recital of consistent uses and practices, are consistent with the Easement. Certain of these consistent uses and practices are identified below as being subject to specified conditions or to the requirement of and procedures for prior approval by the Conservancy as described in Paragraph $\mathrm{E}$; the remainder of these consistent uses shall not be precluded, prevented, or limited by the Easement.

1. To use the existing house as a year-round residence for a single family and, if desired, to replace or reconstruct the existing house at its current location.

Copper Gulch CE September 4, 1990 
2. To construct, within one hundred (100) feet of the existing cleared area, no more than one additional single family dwelling on the Property and to construct necessary outbuildings associated with the uses of the Property authorized by the Easement; provided that Grantor must notify the Conservancy of the location of any new dwelling or outbuilding prior to the commencement of construction and provided that the proposed building, its location, or associated construction activities do not adversely affect critically important habitat for rare animals, plants, or plant communities identified in the Environmental Documentation Report.

3. To construct a road to access any new dwelling and associated outbuildings; provided that Grantor notifies the Conservancy prior to road construction of the location and construction methods of the road and, further, that the road does not violate the purposes of the Easement.

4. To graze and pasture cattle, horses, and/or llamas; provided that such grazing does not cause accelerated erosion or damage the productivity of the soil.

5. To maintain, repair, and, in the event they are destroyed, reconstruct existing fencing, and to construct new fences. Boundary or pasture-division fences shall not prevent or unduly restrict or exclude wildlife from the Property, but other fencing may exclude wildlife from residential yard areas, gardens, orchards, and areas associated with any domestic bird or waterfowl enclosures.

6. To maintain, repair, and in the event of their destruction, reconstruct existing buildings and those new buildings provided for hereunder in their original location and of similar size and function. If practicable, all new roofs, exterior siding, plumbing, vent pipes, chimneys, drain gutters, downspouts, and other exterior materials and fixtures shall be constructed of nonreflective material and painted or maintained with earth-tone 
colors found in the surrounding environment.

7. To maintain, repair, and in the event of their destruction, reconstruct the existing water facilities (including the existing pond), and, subject to approval by the Conservancy as provided for in Paragraph E, to develop new water resources and facilities; provided that any maintenance, repair, reconstruction, or construction activities do not cause significant or long-term impairment of the water quality or riparian values of Copper Creek.

8. To use agricultural chemicals for the following purposes and under the following conditions:

a. For the control of noxious weeds, as required by Montana law, and for the control of other invasive exotic plant species; provided that chemical herbicides may be used only in those amounts and with a frequency of application that constitute the minimum necessary for control, that rare or unique native plants are not exposed to any herbicide, and that the herbicide is not applied by aerial spraying;

b. For the control of agricultural pests; provided that chemical biocides may be used only when no other method of control is effective, that the biocide is used only in those amounts and with a frequency of application constituting the minimum necessary to accomplish reasonable grazing, agricultural, and residential purposes, and that the biocide use does not adversely affect ecosystem function or nontarget species of plants or animals;

c. For fertilizing orchard or pasture crops; provided that fertilizers are used in a manner that minimizes any adverse effect upon the aquatic or terrestrial ecosystems.

9. To introduce biological weed and insect control agents, subject to prior approval by the Conservancy as provided for in Paragraph E.

10. Subject to the restrictions stated herein and in accordance with all applicable state or federal laws, to use 
selective techniques to control specific predatory and problem animals, excluding raptors, that have caused damage to livestock or other property. Any control effort targeted at bears or potentially affecting bears is subject to prior approval by the Conservancy, as provided for in Paragraph E, and Grantor and the conservancy shall consult with the Department of Fish, Wildlife and Parks prior to implementing such a control effort. Grantor retains no right to use poison bait, cyanide guns, or other nonselective control techniques, or to undertake any control activity that is not in accordance with state or federal law.

11. To construct utility systems for the residential, ranching, and agricultural uses permitted herein; provided, however, that Grantor shall bury, if practicable, all utility systems or extensions of existing utility systems constructed after the effective date of the Easement, and further provided that any satellite dish antenna shall be of a color intended to blend with the surrounding environment.

12. Provided that the conditions of Subparagraphs 12a through $12 \mathrm{~d}$ are met, to selectively harvest timber only for the purposes of controlling an imminent threat of disease; protecting persons or property from the hazards of falling trees or branches; providing firewood for domestic use on the Property; providing logs for construction of the buildings approved hereunder; maintaining the existing field and open pastures; or enhancing wildlife habitat.

a. Any timber harvest exceeding 25 trees (including living or standing dead trees) in a year must be approved by the Conservancy as provided for in Paragraph E.

b. Timber harvest must be conducted using best management practices, including stringent protection of soil and watershed values, riparian areas, and wildlife habitat.

c. The cutting or disturbance of any tree or vegetation within 660 feet of any active or inactive raptor nest, currently known or later identified, is prohibited; except that 
during the non-nesting season diseased trees, not including any raptor nesting tree itself, may be cut and removed to abate infestation.

d. The cutting of standing dead trees (snags) with a diameter breast height (dbh) exceeding 18 inches or with evident bird or mammal nest holes or dens is prohibited, unless approved by the Conservancy as provided for in Paragraph $E$.

13. To keep domestic pets; provided that each pet is under the control of a responsible person and does not harass any wildlife.

14. To raise game birds or waterfowl in accordance with state and federal laws and in a manner that does not attract bears or other predatory wildlife.

15. Subject to prior approval by the Conservancy as provided for in Paragraph $\mathrm{E}$ and in conformance with state law, to introduce into the pond species of fish native to the Bull River drainage.

16. a. To prune, harvest, and plant trees to maintain the noncommercial orchard; provided that the orchard may not be expanded beyond its existing location in the fenced yard area and provided that orchard crops are managed so that they do not become an attraction to bears.

b. In the event that an additional single family dwelling is developed on the Property in accordance with the terms of the Easement, to establish and maintain a second noncommercial orchard not exceeding two acres; provided that orchard crops are managed so that they do not become an attraction to bears.

17. To cultivate, harvest, seed, and otherwise maintain or improve the existing field and open pasture delineated in the Environmental Documentation Report,

18. To conduct, only through the use of simple tools, such as pick, shovel, and gold-washing pan, the noncommercial exploration for and extraction of small quantities of minerals, 
soil, sand, gravel, or rock.

E. Prior Notice and Approval. Grantor shall not undertake or permit any activity requiring prior approval of the Conservancy without first having notified and received approval from the Conservancy as provided herein.

Prior to the commencement of any such activity, Grantor shall send the Conservancy written notice of his intention to undertake or permit such activity. The notice shall inform the Conservancy of all aspects of the proposed activity, including location, design, materials or equipment to be used, dates and duration, and any other relevant information, and shall be sent by registered or certified mail, return receipt requested, to The Nature Conservancy, Montana Field Office, Post Office Box 258, Helena, Montana 59624, with a copy to the Western Regional Attorney, The Nature Conservancy, 785 Market Street, Third Floor, San Francisco, California 94103, or such other addresses as Grantor may be from time to time informed of in writing by the Conservancy.

The Conservancy shall have thirty (30) days from receipt of the notice, as indicated by the date of the return receipt, to review the proposed activity and to notify Grantor of any objections thereto; provided that the 30-day period shall not begin until such time as the Conservancy has received adequate information from Grantor to evaluate the proposed activity. In the event that the Conservancy requires additional information to evaluate the proposed activity, the Conservancy shall request the information from Grantor as soon as practicable and in any case not later than 20 days after the receipt of the notice of the proposed activity.

The Conservancy's decision to approve or disapprove the activity proposed by Grantor shall be sent by registered or certified mail, return receipt requested, to Grantor at the address first stated above, or to such other address as the Conservancy may 
from time to time be informed of in writing by Grantor.

A decision by the Conservancy to disapprove a proposed activity must be based upon the Conservancy's determination that the proposed activity is inconsistent with the conservation purposes of the Easement. If in the Conservancy's judgment it is possible that the proposed activity can be modified to be consistent with the easement, the Conservancy's decision notice shall inform Grantor of such modification(s). Once modification is made to the satisfaction of the Conservancy or the Conservancy otherwise concurs with the matters set forth in Grantor's notice, the proposed activity may thereafter be conducted in a manner that is acceptable to the Conservancy.

Should the Conservancy fail to post its response to Grantor's notice within thirty (30) days of its receipt of notice or within thirty (30) days of the time that the Conservancy has received adequate information to evaluate the proposed activity, whichever is later, the proposed activity is automatically deemed consistent with the terms of the Easement, the Conservancy having no further right to object to the activity identified by such notice.

F. Inconsistent Uses of the Property. The following uses and practices on the Property, though not an exhaustive recital of inconsistent uses and practices, are inconsistent with the Easement and shall be prohibited:

1. The change, disturbance, alteration, or impairment of the significant relatively natural ecological features and values or the destruction of other significant conservation interests on the Property, except as specifically authorized in the Easement.

2. The conversion of native vegetation to exotic cover species or the introduction of nonnative plant species, except for gardening, residential landscaping, orchard-management activities authorized in Paragraph D15, or pasture-maintenance activities 
authorized in Paragraph D16.

3. The introduction of nonnative animal species, except that the grazing of domestic livestock, keeping of pets, raising of game birds or waterfowl, and introduction of biological control agents is permitted as specifically provided for in the Easement.

4. a. Filling, excavating, dredging, mining, and drilling, and the exploration for or extraction of minerals, hydrocarbons, soils, sand, gravel, rock, or other materials on or below the surface of the Property, except for the restricted noncommercial exploration and extraction provided for in Paragraph D17.

b. Use of the Property to carry out or facilitate any of the commercial earth-moving or mineral-related activities described in Paragraph $4 \mathrm{a}$ that are conducted on other property adjacent to or nearby the Property.

5. The division, subdivision, or de facto subdivision of the Property.

6. The construction or placement of any buildings, camping accommodations, temporary living quarters of any sort, mobile homes, signs, billboards or other advertising materials, or utility towers or other structures, except that the utilities and the additional residence and outbuildings specifically provided for in the Easement may be constructed and placed and except that vehicular campers owned by Grantor or his guests may be parked on the Property as appropriate to accommodate normal visitation or Grantor's personal storage needs.

7. The construction of roads or vehicle trails, except the access road specifically provided for in the Easement.

a. The use of snowmobiles, all-terrain vehicles, motorcycles, or other motorized vehicles off of roads or travelways, except for agricultural or property-maintenance purposes.

9. The dumping or other disposal of refuse or other 
unsightly, hazardous, or toxic materials.

10. The cutting, removal, or destruction of native vegetation, except by grazing, haying, selective harvest of timber, or building-related construction activities, all as specifically provided for in the Easement.

11. The application of biocides, defoliants, chemical fertilizers, or other agricultural chemicals, except as specifically provided for in the Easement.

12. The manipulation, diversion, or other alteration of natural water courses, wetlands, or other bodies of water; the construction of ponds, except for the pond maintenance specifically provided for in the Easement: the drainage of surface or subsurface waters; the withdrawal of water from Copper Creek to the extent that the aquatic ecosystem is adversely affected; and any use or activity that would pollute or degrade or threaten to pollute. or degrade the surface or sub-surface waters on or underlying the Property .

13. The changing of the topography of the Property by placing on it any soil, dredging spoils, land fill, or other material.

14. The establishment or maintenance of any commercial or industrial activity, except permitted agricultural. uses or commercial activity that can be conducted from existing or authorized structures in a manner that is otherwise consistent with the conservation purposes of the Easement.

15. The keeping of pigs, sheep, goats, or beehives: the storage or placement of animal food or human food in a manner that is accessible to or attractive to bears or other wildlife; or the establishment of a livestock feedlot.

16. Charging or accepting money or other compensation from persons hunting on the property or from persons crossing the property to gain access to national forest lands for hunting, or charging or accepting money or other compensation for providing or 
for permitting another party to provide guiding or outfitting services to persons hunting on the property or persons crossing the property to gain access to national forest lands for hunting.

G. Remedies, Breach and Restoration. In the event a violation of any restriction contained in Paragraph $F$ hereof, whether by Grantor or a third party, comes to the attention of the Conservancy, the Conservancy shall notify Grantor in writing of the violation. Grantor shall have thirty (30) days after the receipt of such notice to undertake actions, including restoration of the Property, that are reasonably calculated swiftly to correct the conditions caused by such violation. If Grantor fails to take such corrective action, the Conservancy may at its discretion undertake such actions, including appropriate legal proceedings, as are reasonably necessary to effect such corrections, and the cost of such corrections, including the Conservancy"s expenses, court costs, and legal fees, shall be paid by Grantor, provided either Grantor, Grantor's family, any shareholders in the Property, agents, guests, employees or other persons permitted by Grantor are determined to be responsible for the violation.

In the event that Grantor undertakes any activity requiring approval of the Conservancy without or in advance of securing such approval, or undertakes any activity in violation of the terms of the Easement, the Conservancy shall have the right to force the restoration of that portion of the Property affected by the activity to the condition that existed prior to the undertaking of the unauthorized activity. In such case, the costs of restoration and the Conservancy's costs of suit, including reasonable attorneys' fees, shall be borne by Grantor or those of his heirs, personal representatives, or assigns against whom a judgment is entered, or, in the event that the Conservancy secures redress without a completed judicial proceeding, by Grantor or those of his heirs, personal representatives, or assigns who are otherwise 
determined to be responsible for the unauthorized activity.

Enforcement of the terms and provisions of the Easement shall be at the discretion of the Conservancy and any forbearance on behalf of the Conservancy to exercise its rights hereunder in the event of any breach hereof by Grantor, his respective heirs, personal representatives, or assigns, shall not be deemed or construed to be a waiver of the Conservancy's rights hereunder in the event of any subsequent breach.

H. Taxes. Grantor agrees to pay any and all real property taxes and assessments levied by competent authority on the Property and to bear all costs of operation, upkeep, and maintenance of the Property, and does hereby indemnify the Conservancy therefor.

I. Access. Nothing herein contained shall be construed as affording the public access to any portion of the Property.

J. Assignment. The Conservancy may assign the Easement without Grantor's consent; provided that:

1. the Conservancy requires, as a condition of such transfer, that the conservation purposes of the Easement continue to be carried out; and

2. any assignment may be made only to an organization qualified at the time of transfer as an eligible donee under Internal Revenue Code Section 170 (h)(3) or its successor, or any regulations issued thereunder.

K. Change of Conditions. The Conservancy hereby covenants and agrees that in the event that a later unexpected change in the conditions of or surrounding the Property makes impossible or impractical any continued use of the Property for the conservation purposes described herein, and the restrictions are extinguished by judicial proceeding, then, upon the subsequent sale, exchange, 
or condemnation of the Property, the Conservancy will apply its share of any and all proceeds (determined as set forth below) received from such sale, exchange, or taking in a manner consistent with the conservation purposes of the Easement or for the protection of a "relatively natural habitat of fish, wildlife, or plants or similar ecosystem," as that phrase is used in P.L. 96541, 26 USC 170 (L)(4)(a)(ii), as amended and in regulations promulgated thereunder.

The fact that any use of the property that is expressly prohibited by this Easement, or any other use as determined to be inconsistent with the purpose of this Easement, may become greatly more economically valuable than permitted uses, or that neighboring properties may in the future be put entirely to uses that are not permitted thereunder, has been considered by the Grantor in granting this Easement. It is Grantor's belief that any such changes will increase the benefit to the public of the continuation of this Easement, and it is the intent of both Grantor and the Conservancy that any changes should not be assumed to be circumstances justifying the termination or extinguishment of this Easement pursuant to this paragraph. In addition, the inability to carry on any or all of the permitted uses, or the unprofitability of doing so, shall not impair the validity of this Easement or be considered grounds for its termination or extinguishment pursuant to this paragraph.

L. Subsequent Sale. Exchange or Involuntary Conversion. Grantor and the Conservancy agree that the donation of the Easement shall give rise to a property right, immediately vested in the Conservancy which, for purposes of this Paragraph, parties stipulate to have a fair market value determined by multiplying the fair market value of the Property unencumbered by the Easement (minus any increase in value after the date of this grant attributable to improvements) by the ratio of the value of the 
Easement at the time of this grant to the value of the Property, without deduction for the value of the Easement, at the time of this grant. The values at the time of this grant shall be those values used to calculate the deduction for federal income tax purposes allowable by reason of this grant, pursuant to Internal Revenue code Section $170(\mathrm{~h})$. For the purposes of this paragraph, the ratio of the value of the Easement to the value of the Property unencumbered by the Easement shall remain constant. Should a change in conditions give rise to the extinguishment of this Easement (as provided in Treas. Reg. Section 1.170A-14(g)(6)(i)), the Conservancy, on a subsequent sale, exchange, or involuntary conversion of the Property, shall be entitled to a portion of the proceeds at least equal to such proportionate value of this Easement as established at the time of its creation, unless under the laws of Montana Grantor shall be entitled to the full proceeds from the sale, exchange, or conversion without regard to the terms of this Easement.

M. Amendment. If circumstances arise under which an amendment to or modification of the Easement would be appropriate, Grantor and the Conservancy may jointly amend the Easement; provided that no amendment shall be allowed that affects the qualification of the Easement or the status of grantee under any applicable laws, including Section $170(\mathrm{~h})$ of the Internal Revenue Code of 1986, as amended, or Section 76-6-201, et seg., MCA. Any such amendment shall be consistent with the purposes of the Easement, shall not affect its perpetual duration, shall not permit additional development or improvements to be undertaken on the Property other than development or improvements currently permitted by the Easement, and shall not impair any of the significant conservation values of the Property. Any such amendment shall be recorded in the official records of Sanders County, Montana.

Copper Gulch CE 
N. Interpretation. The provisions of this Conservation Easement shall be liberally construed to effectuate their purpose of preserving and protecting habitat for grizzly bears and other wildlife, unique native plants, and diverse riparian and forest vegetative communities. No remedy or election given by any provision in this Easement shall be deemed exclusive unless so indicated, but it shall, wherever possible, be cumulative with all other remedies at law or in equity. The parties acknowledge that each party and its counsel have reviewed and revised this Easement and that no rule of construction that ambiguities are to be resolved against drafting party shall be employed in the interpretation of this Easement. In the event of any conflict between the provisions of this Easement and the provisions of any use and zoning restrictions of the state of Montana, Sanders County, or any other governmental entity with jurisdiction, the more restrictive provisions shall apply. This Easement shall be interpreted in accordance with the laws of the State of Montana.

\section{Miscellaneous.}

1. The terms "Grantor" and "Conservancy" as used herein shall be deemed to include, respectively, the Grantor, his heirs successors, personal representatives, and assigns, and the Conservancy, its successors and assigns.

2. Grantor intends that the Easement shall run with and burden title to the Property in perpetuity, and shall bind Grantor, his heirs, personal representatives, and assigns.

3. If any provision of this Deed of Conservation Easement or the application thereof to any person or circumstance is found to be invalid, the remainder of the provisions hereof and the application of such provision to persons or circumstances other than those to which it is found to be invalid, shall not be affected thereby.

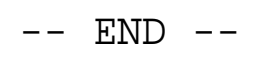

$-17-$
Copper Gulch $\mathrm{CE}$ September 4, 1990 
IN WITNESS WHEREOF, Grantors have hereunto set their hand this day of 1990.

STATE OF MONTANA

$\{\mathrm{sS}$.

County of

On this day of 1990 before me, the undersigned, a Notary Public in and for said state, personally appeared and

known to me to be the persons whose name are subscribed to the within instrument, and acknowledged to me that they executed the same.

IN WITNESS WHEREOF, I have hereunto set my hand and affixed my official seal the day and year first above written.

Notary Public, Residing at Montana.

My commission expires: 
The Property

Homestead Entry Survey \#851, in Sections 19 and 20, Township 27 North, Range 32 West, P.M.M., Sanders County, Montana, by metes and bounds :

Tract "A", beginning at a point called corner No. 1, whence the quarter corner of East boundary of Section 24, T27N, R33W bears South 82*35' West 56.87 chains, thence

North 39*43' East 9.39 chains to corner No. 2, thence

North 86*43' East 14.88 chains to corner No. 3, thence

South 83*14' East 57.14 chains to corner No. 4, thence

South $2 * 47$ West 2.64 chains to corner No. 5, thence

North $86 * 48^{\prime}$ West 16.49 chains to corner No. 6, thence

South $74 * 41$ West 14.20 chains to corner No. 7, thence

North 89*06' West 27.36 chains to corner No. 8, thence

North 79*28' West 20.32 chains to corner No. 1, the place of beginning .

Tract "B" commencing at corner No. 9, thence

North $70 * 56$ East 26.61 chains to corner No. 10, thence

South 79*51' East 18.23 chains to corner No. 11, thence

South 62*53' East 14.43 chains to corner No. 12, thence

South 2*47 West 5.54 chains to corner No. 13, thence

North $83 * 14$ ' West 56.08 chains to corner No.9, the place of beginning

Road Tract "C" commencing at corner No. 3, thence

South 83*14' East 57.14 chains to corner No. 4, thence North 2*47' East. 502 chains to corner No. 13, thence North 83*14' West 56.08 chains to corner No. 9, thence South 70*56' West 1.148 chains to corner No. 3, the place of beginning .

* $=$ degrees

107 acres

(According to Book 49 of Deeds, Page 277) 
Acknowledgement of Easement Documentation Report

Grantor and the Conservancy acknowledge that each has read the "Copper Gulch Conservation Easement Documentation Report", prepared by Western Technology and Engineering, Inc., of Helena, Montana, and dated september 1990 and that the report accurately reflects the condition of the Property subject to the Easement as of the date of conveyance of the Easement.

For Copper Creek Conserve, Inc.

$\overline{\text { Date }}$
For The Nature Conservancy

Date 
APPENDIX F

The Potentiall Affected Interests (PAI's) identified in the Columbian Sharp-tailed Grouse Program. 


\section{Columbia Sharp-tailed Grouse Mitigation Program}

Potentially Affected Interests

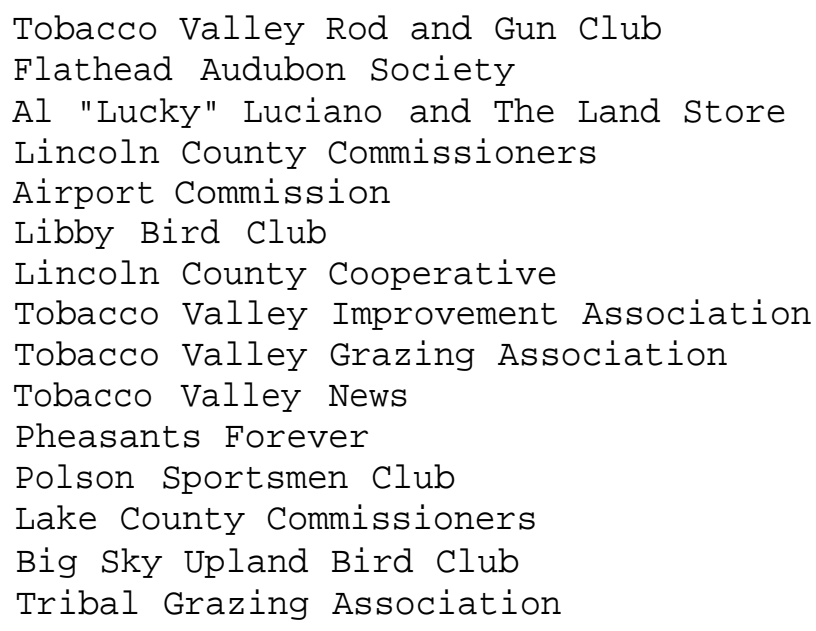


APPENDIX.

The report on the Columbian sharp-tailed grouse population in the Tobacco Valley, Eureka, Montana. 